\title{
Naphthacemycins from a Streptomyces sp. as Protein-Tyrosine Phosphatase Inhibitors
}

Changhong Huo, ${ }^{* \dagger}$ Zhihui Zheng, ${ }^{\ddagger}$ Yan Xu, ${ }^{\ddagger}$ Yanbo Ding, ${ }^{\ddagger}$ Haizhou Zheng, ${ }^{\ddagger}$ Yunlong Mu, ${ }^{\ddagger}$ Yuanchen Niu, ${ }^{\S}$ Jian Gao, ${ }^{\star}$ Xinhua $\mathrm{Lu}^{* *}$

${ }^{\dagger}$ School of Pharmaceutical Sciences, Hebei Medical University, Shijiazhuang 050017, People’s Republic of China

${ }^{\ddagger}$ New Drug Research and Development Center, North China Pharmaceutical Group Corporation, National Microbial Medicine Engineering and Research Center, Hebei Industry Microbial Metabolic Engineering \& Technology Research Center, Key Laboratory New Drug Screening Technology of Shijiazhuang City, Shijiazhuang 050015, People's Republic of China

${ }^{\S}$ School of Pharmaceutical Sciences, Xiamen University, Xiamen 361102, People’s Republic of China

\section{Table of Contents}

S1 HRESIMS for compound 1

S2 ${ }^{1} \mathrm{H}$ NMR and the expansion spectra of the aromatic region for compound 1 (500 MHz, Acetone- $\left.d_{6}\right)$

S3 ${ }^{13} \mathrm{C}$ NMR compound $1\left(125 \mathrm{MHz}\right.$, Acetone- $\left.d_{6}\right)$

S4 HSQC for compound 1 (500 MHz, Acetone- $\left.d_{6}\right)$

S5 HMBC for compound 1 (500 MHz, Acetone- $\left.d_{6}\right)$

S6 HRESIMS for compound 2

S7 $\quad{ }^{1} \mathrm{H}$ NMR and the expansion spectra of the aromatic region for compound 2 (500 MHz, Acetone- $d_{6}$ )

S8 ${ }^{13} \mathrm{C}$ NMR for compound $2\left(125 \mathrm{MHz}\right.$, Acetone- $\left.d_{6}\right)$

S9 HSQC for compound $2\left(500 \mathrm{MHz}\right.$, Acetone- $\left.d_{6}\right)$

S10 HMBC for compound 2 (500 MHz, Acetone- $d_{6}$ ) 
S11 HRESIMS for compound 3

S12 ${ }^{1} \mathrm{H}$ NMR and the expansion spectra of the aromatic region for compound 3 (500 MHz, Acetone- $d_{6}$ )

S13 ${ }^{13} \mathrm{C}$ NMR for compound 3 (125 MHz, Acetone- $\left.d_{6}\right)$

S14 HSQC for compound $3\left(500 \mathrm{MHz}\right.$, Acetone- $\left.d_{6}\right)$

S15 HMBC for compound $3\left(500 \mathrm{MHz}\right.$, Acetone- $\left.d_{6}\right)$

S16 HRESIMS for compound 4

S17 ${ }^{1} \mathrm{H}$ NMR and the expansion spectra of the aromatic region for compound 4 (500 MHz, Acetone- $d_{6}$ )

S18 ${ }^{13} \mathrm{C}$ NMR for compound 4 (125 MHz, Acetone- $\left.d_{6}\right)$

S19 HSQC for compound 4 (500 MHz, Acetone- $\left.d_{6}\right)$

S20 HMBC for compound $4\left(500 \mathrm{MHz}\right.$, Acetone- $\left.d_{6}\right)$

S21 HRESIMS for compound 5

S22 ${ }^{1} \mathrm{H}$ NMR and the expansion spectra of the aromatic region for compound $5\left(500 \mathrm{MHz}\right.$, Acetone- $\left.d_{6}\right)$

S23 ${ }^{13} \mathrm{C}$ NMR for compound 5 (125 MHz, Acetone- $\left.d_{6}\right)$

S24 HSQC for compound 5 (500 MHz, Acetone- $\left.d_{6}\right)$

S25 HMBC for compound $5\left(500 \mathrm{MHz}\right.$, Acetone- $\left.d_{6}\right)$

S26 HRESIMS for compound 6

S27 ${ }^{1} \mathrm{H}$ NMR and the expansion spectra of the aromatic region for compound $6\left(500 \mathrm{MHz}\right.$, Acetone- $\left.d_{6}\right)$

S28 ${ }^{13} \mathrm{C}$ NMR for compound $6\left(125 \mathrm{MHz}\right.$, Acetone- $\left.d_{6}\right)$

S29 HSQC for compound 6 (500 MHz, Acetone- $\left.d_{6}\right)$

S30 HMBC for compound $6\left(500 \mathrm{MHz}\right.$, Acetone- $\left.d_{6}\right)$

S31 HRESIMS for compound 7

S32 ${ }^{1} \mathrm{H}$ NMR and the expansion spectra of the aromatic region for compound $7\left(500 \mathrm{MHz}, \mathrm{CDCl}_{3}\right)$

S33 ${ }^{13} \mathrm{C}$ NMR for compound $7\left(125 \mathrm{MHz}, \mathrm{CDCl}_{3}\right)$

S34 HSQC for compound $7\left(500 \mathrm{MHz}, \mathrm{CDCl}_{3}\right)$

S35 HMBC for compound $7\left(500 \mathrm{MHz}, \mathrm{CDCl}_{3}\right)$

S36 HRESIMS for compound $\mathbf{8}$

S37 ${ }^{1} \mathrm{H}$ NMR and the expansion spectra of the aromatic region for compound $8\left(500 \mathrm{MHz}, \mathrm{CDCl}_{3}\right)$

$\mathrm{S} 38{ }^{13} \mathrm{C}$ NMR for compound $8\left(125 \mathrm{MHz}, \mathrm{CDCl}_{3}\right)$ 
S39 HSQC for compound $8\left(500 \mathrm{MHz}, \mathrm{CDCl}_{3}\right)$

S40 HMBC for compound $8\left(500 \mathrm{MHz}, \mathrm{CDCl}_{3}\right)$

S41 HRESIMS for compound 9

S42 ${ }^{1} \mathrm{H}$ NMR and the expansion spectra of the aromatic region for compound 9 (500 MHz, DMSO- $d_{6}$ )

S43 ${ }^{13} \mathrm{C}$ NMR for compound $9\left(125 \mathrm{MHz}, \mathrm{DMSO}-d_{6}\right)$

S44 HSQC for compound 9 (500 MHz, DMSO- $\left.d_{6}\right)$

S45 HMBC for compound 9 (500 MHz, DMSO- $\left.d_{6}\right)$

S46 HRESIMS for compound $\mathbf{1 0}$

S47 ${ }^{1} \mathrm{H}$ NMR and the expansion spectra of the aromatic region for compound $10\left(500 \mathrm{MHz}\right.$, Acetone- $\left.d_{6}\right)$

S48 ${ }^{13} \mathrm{C}$ NMR for compound 10 (125 MHz, Acetone- $\left.d_{6}\right)$

S49 HSQC for compound $10\left(500 \mathrm{MHz}\right.$, Acetone- $\left.d_{6}\right)$

S50 HMBC for compound $10\left(500 \mathrm{MHz}\right.$, Acetone- $\left.d_{6}\right)$

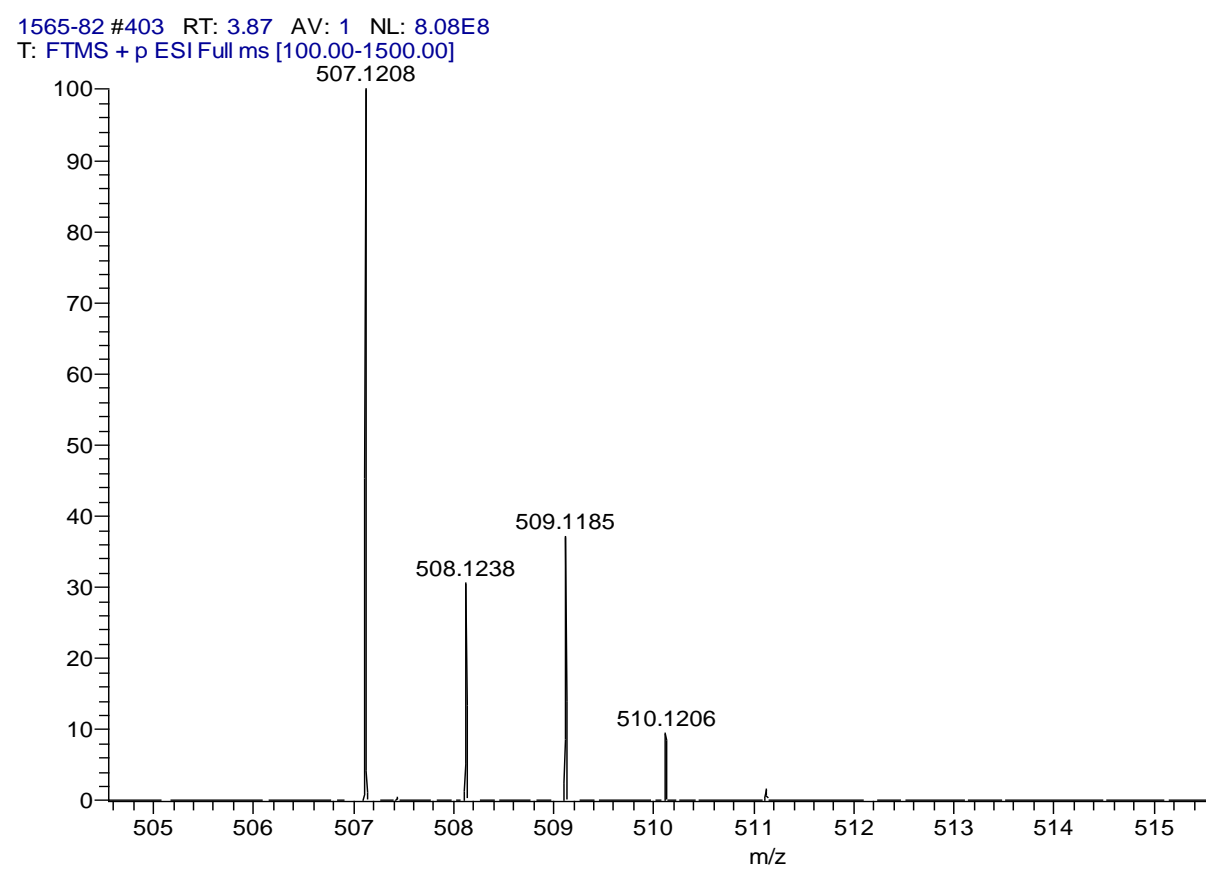

S1 HRESIMS for compound 1 


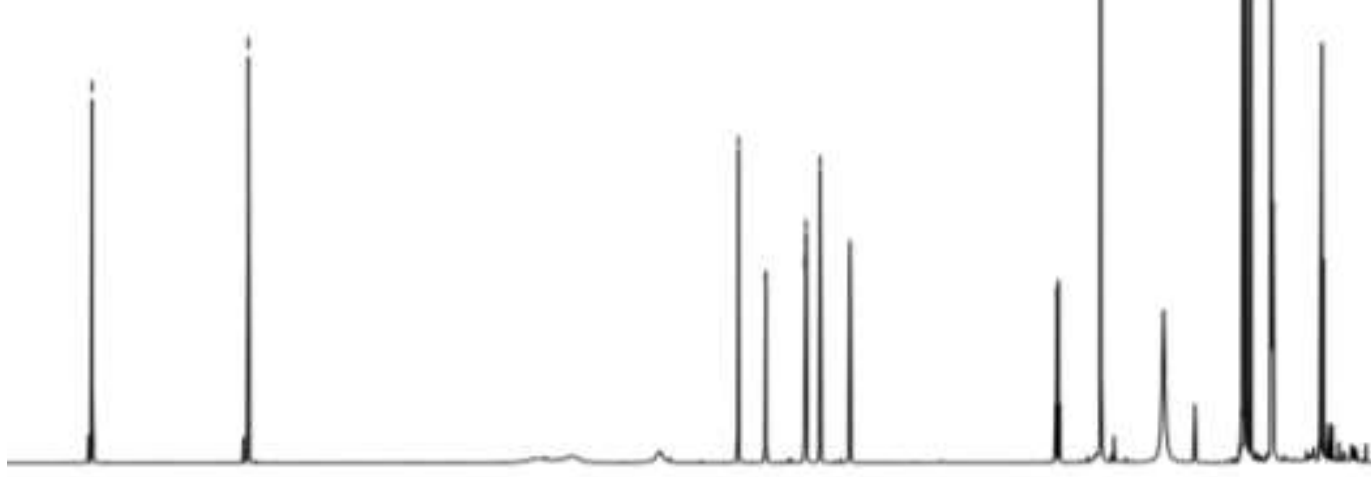

\begin{tabular}{|c|c|c|c|c|c|c|c|c|c|c|c|c|c|c|}
\hline 15 & 14 & 13 & 12 & 11 & 10 & 9 & $\begin{array}{l}8 \\
\mathrm{f} \\
\mathrm{f}\end{array}$ & 6 & 5 & 4 & 3 & 2 & 1 & 0 \\
\hline
\end{tabular}

\begin{tabular}{|c|c|c|}
\hline$\stackrel{5}{n}$ & 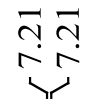 & 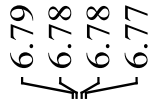 \\
\hline
\end{tabular}
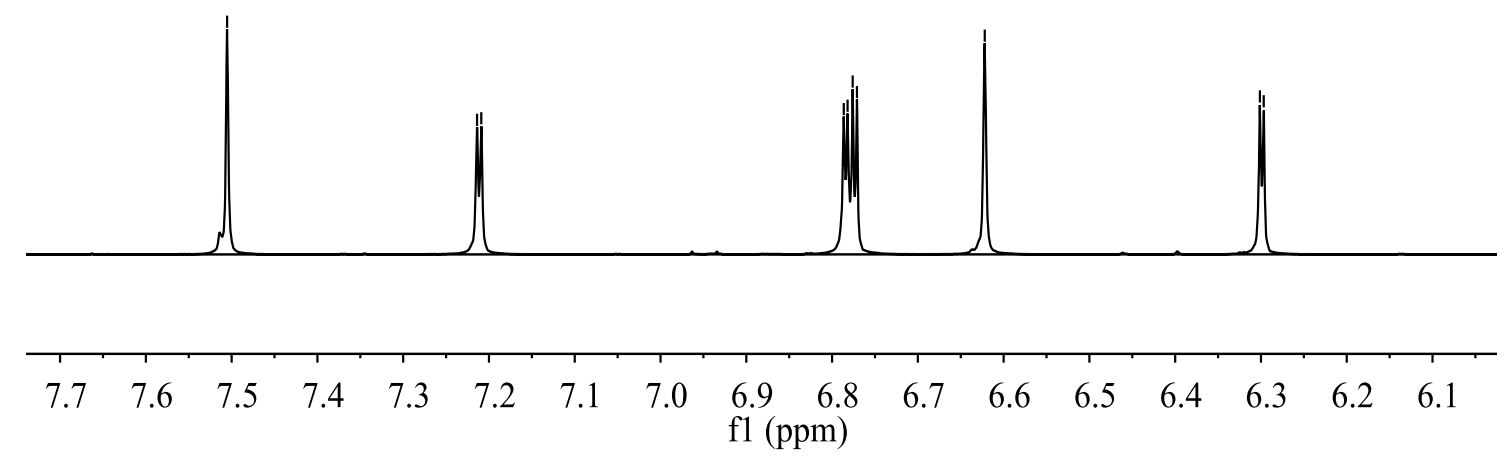

S2 ${ }^{1} \mathrm{H}$ NMR and the expansion spectra of the aromatic region for compound 1 (500 MHz, Acetone- $\left.d_{6}\right)$ 


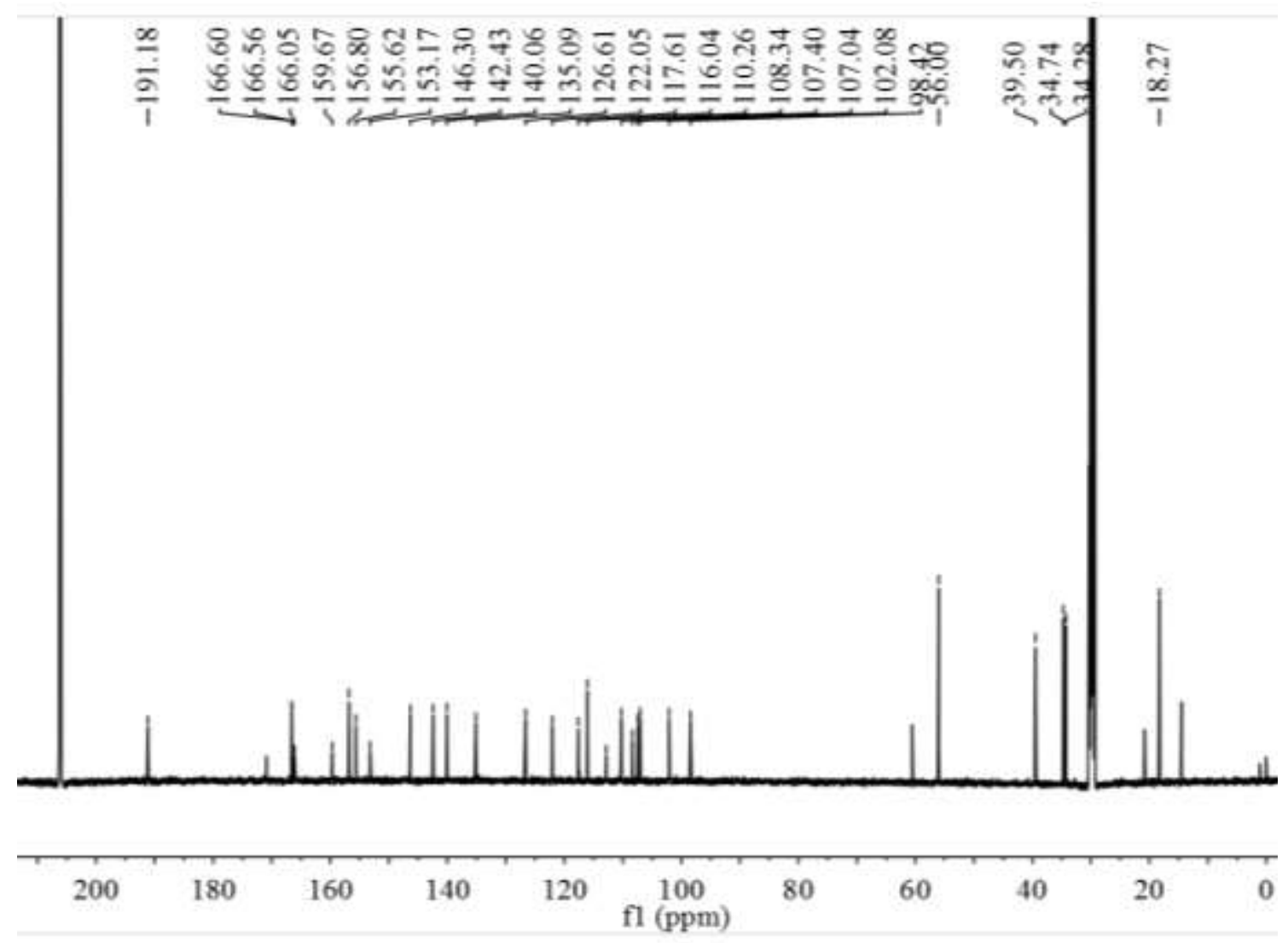

S3 ${ }^{13} \mathrm{C}$ NMR for compound $\mathbf{1}\left(125 \mathrm{MHz}\right.$, Acetone- $\left.d_{6}\right)$

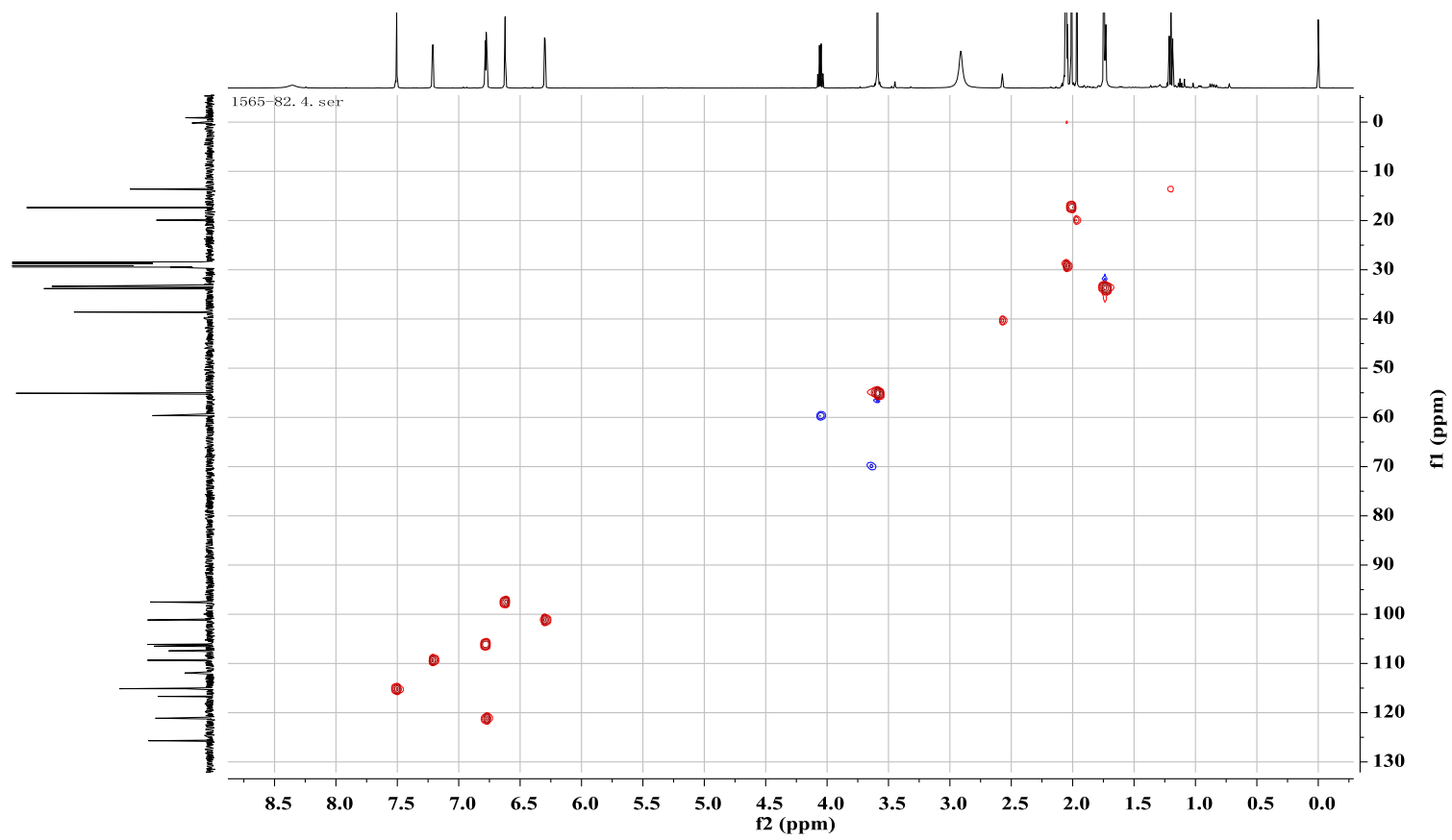

S4 HSQC for compound 1 (500 MHz, Acetone- $d_{6}$ ) 


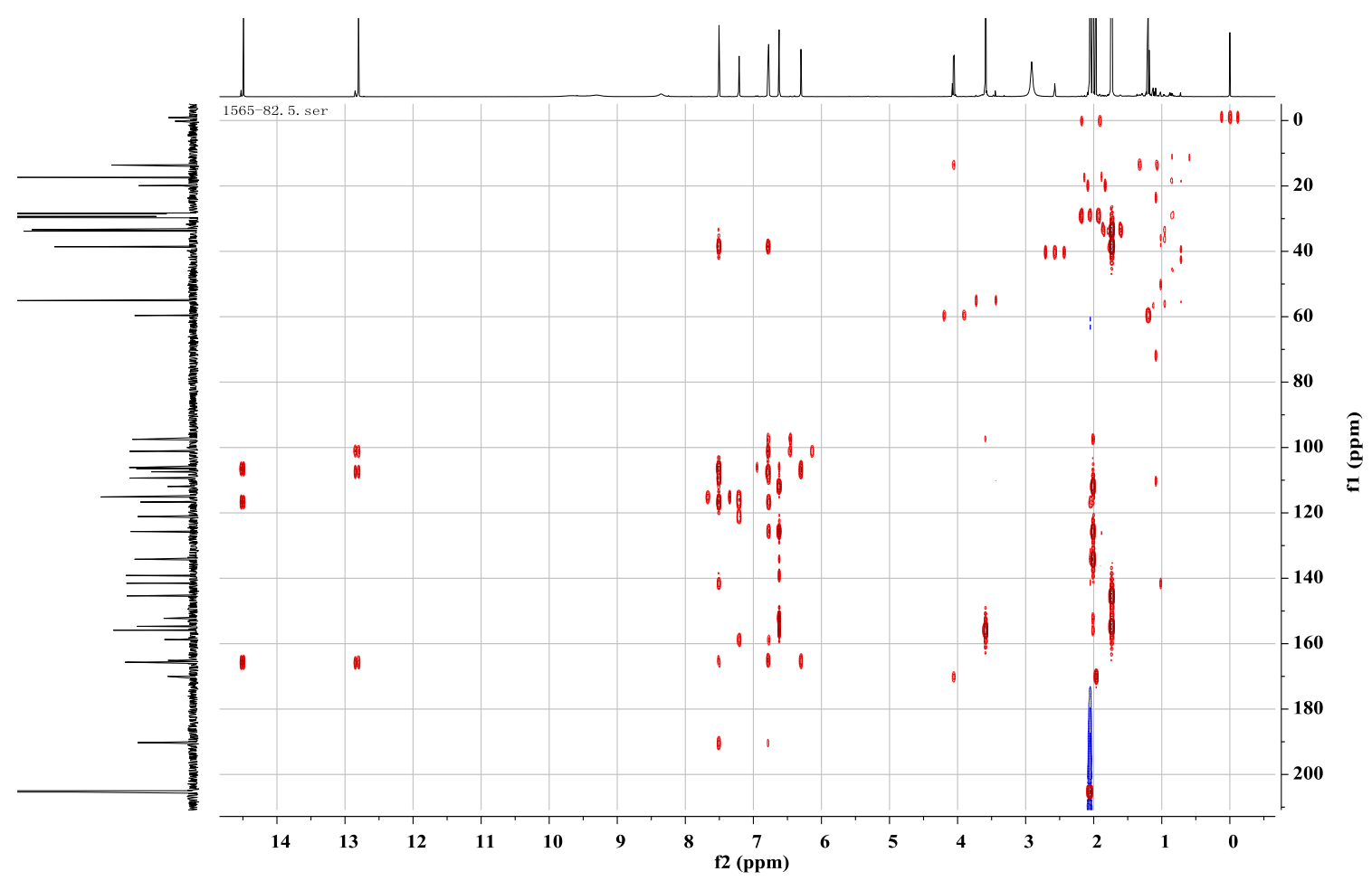

S5 HMBC for compound $1\left(500 \mathrm{MHz}\right.$, Acetone- $d_{6}$ )

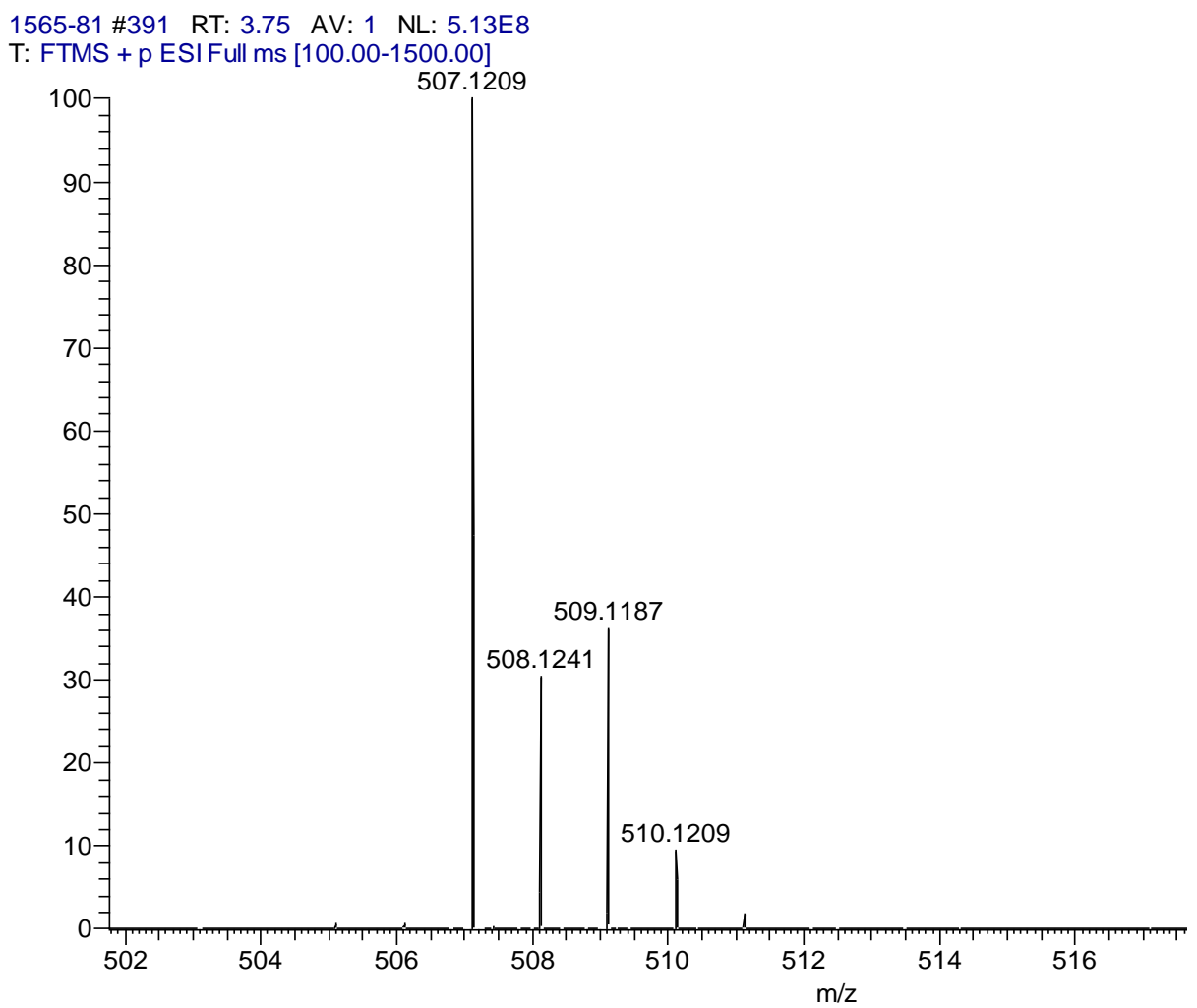

S6 HRESIMS for compound 2 

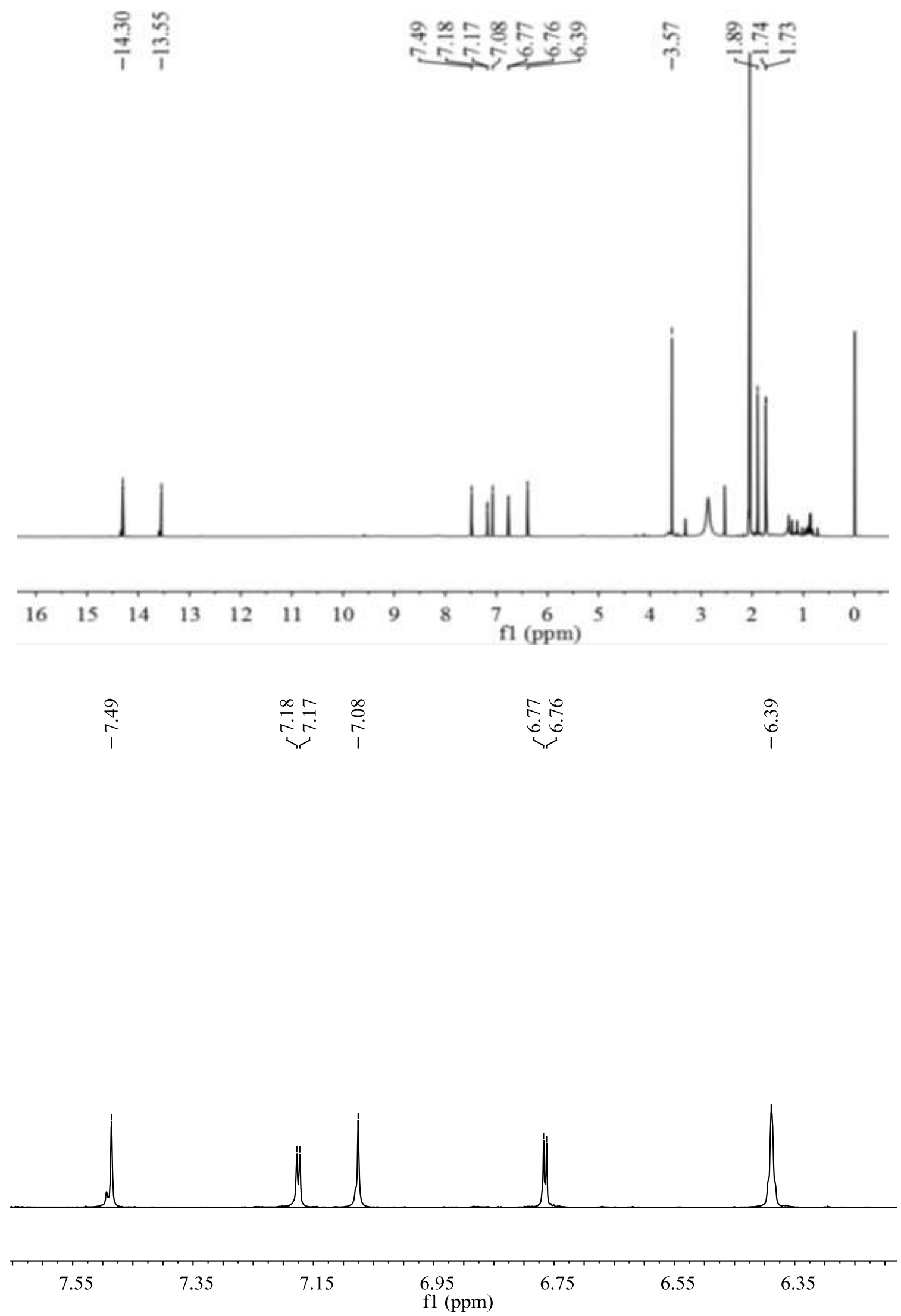

S7 $\quad{ }^{1} \mathrm{H}$ NMR and the expansion spectra of the aromatic region for compound 2 (500 MHz, Acetone- $d_{6}$ ) 


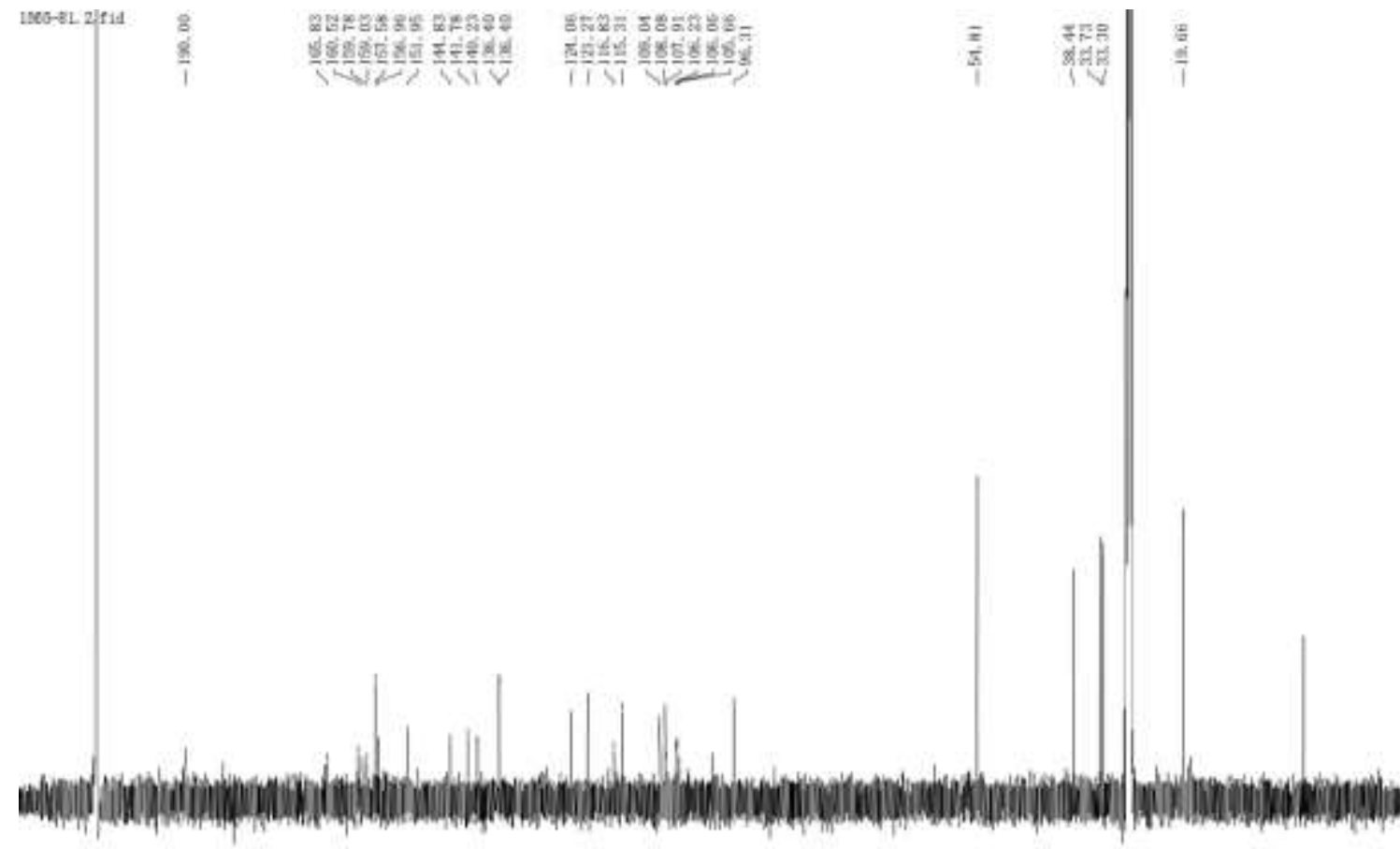

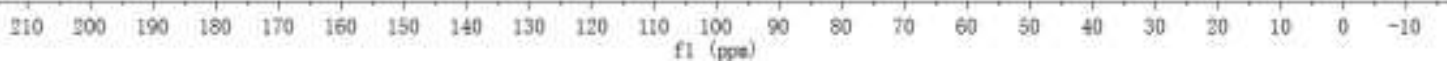

S8 ${ }^{13} \mathrm{C}$ NMR for compound $2\left(125 \mathrm{MHz}\right.$, Acetone- $\left.d_{6}\right)$

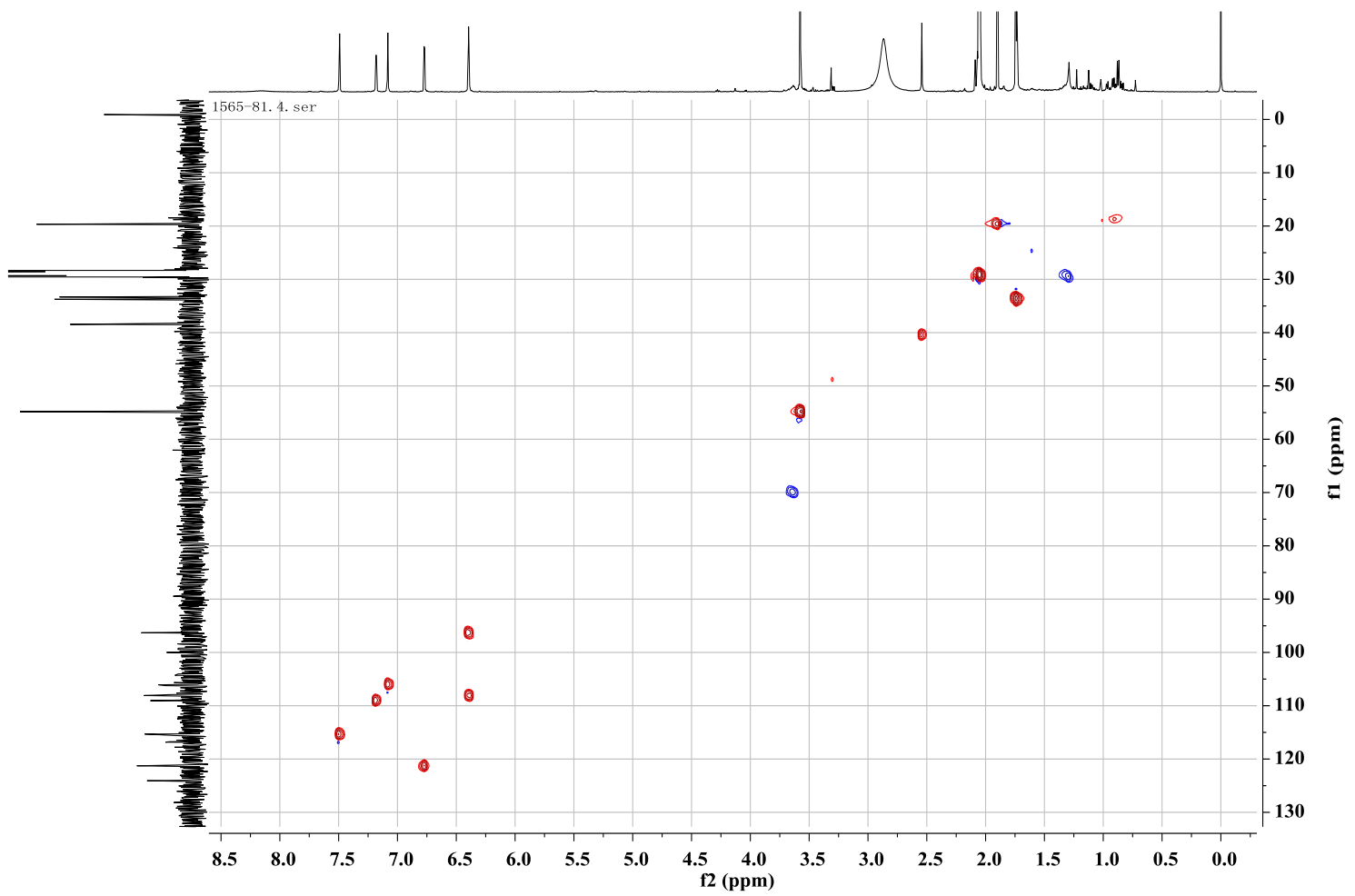

S9 HSQC for compound 2 (500 MHz, Acetone- $d_{6}$ ) 


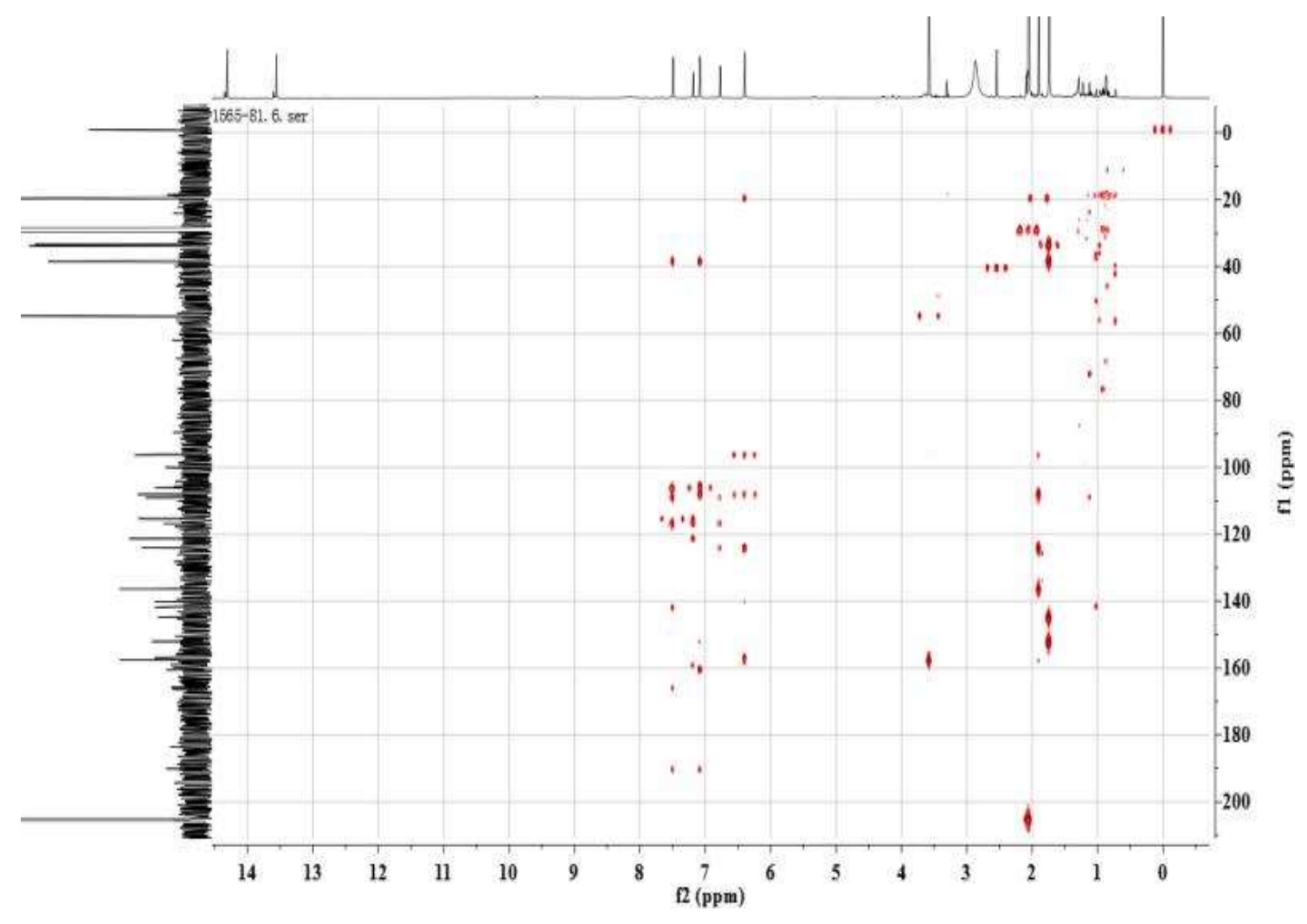

S10 HMBC for compound $2\left(500 \mathrm{MHz}\right.$, Acetone- $\left.d_{6}\right)$

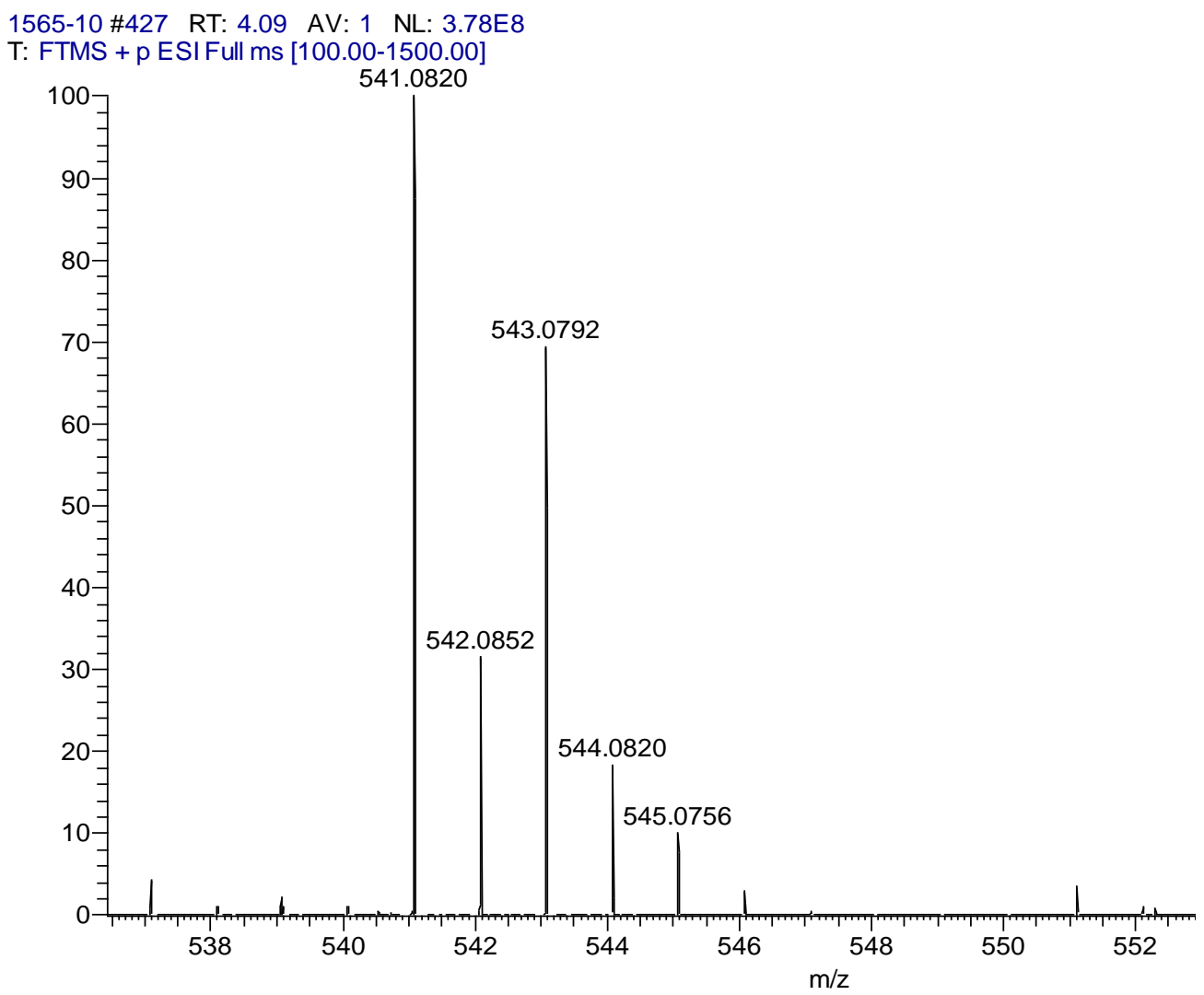

S11 HRESIMS for compound 3 

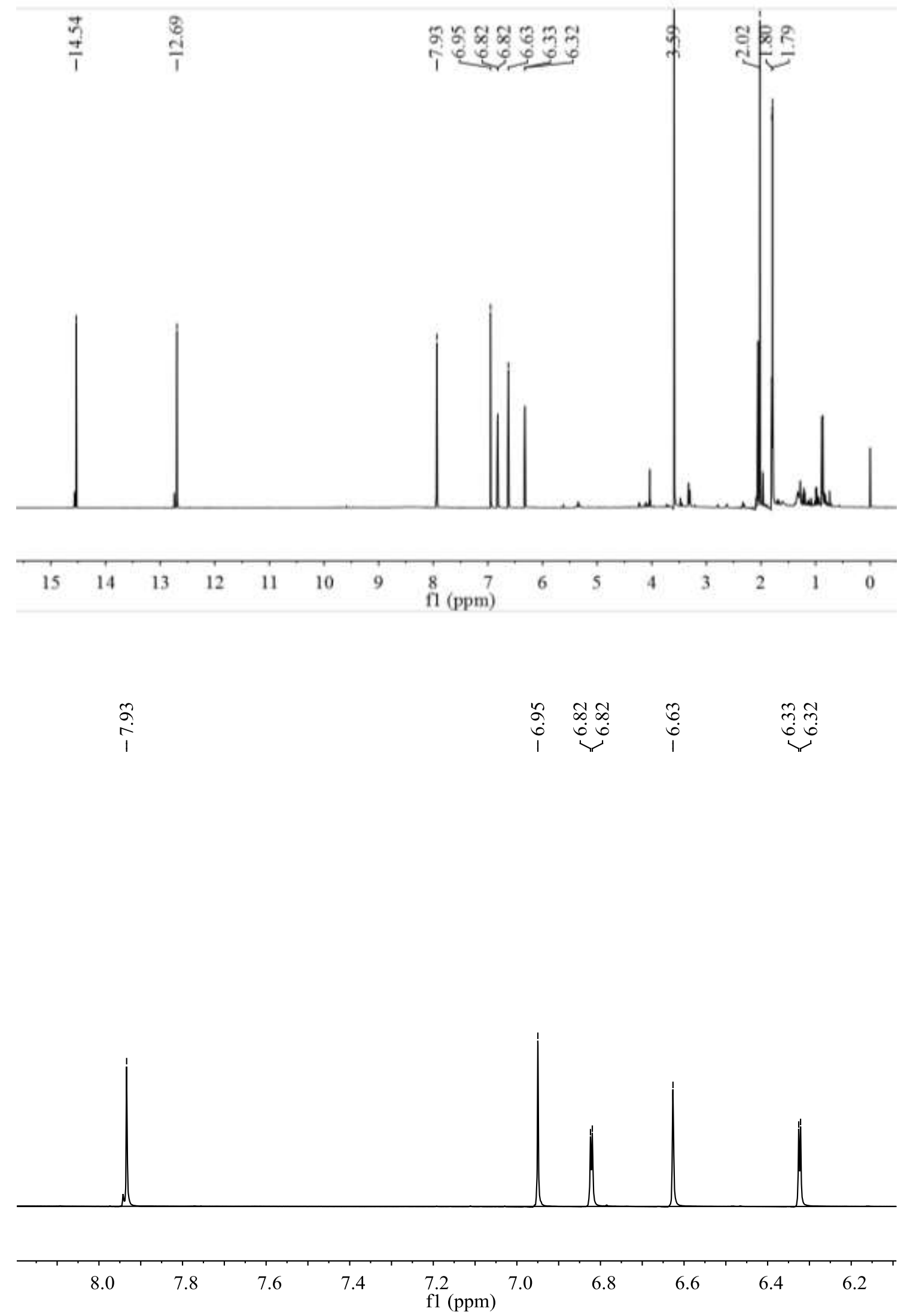

S12 ${ }^{1} \mathrm{H}$ NMR and the expansion spectra of the aromatic region for compound $3\left(500 \mathrm{MHz}\right.$, Acetone- $\left.d_{6}\right)$ 


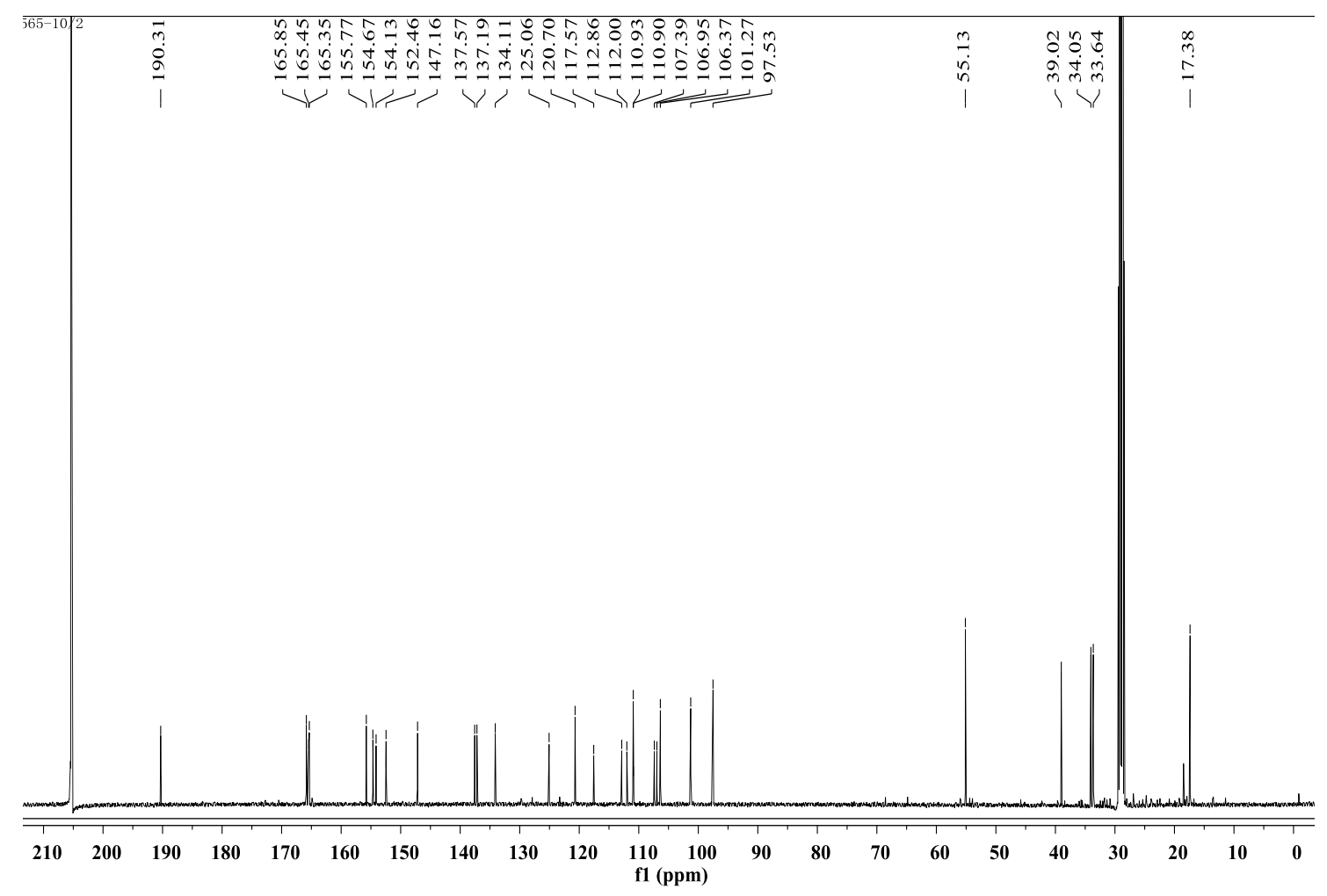

S13 ${ }^{13} \mathrm{C}$ NMR for compound 3 (125 MHz, Acetone- $d_{6}$ )

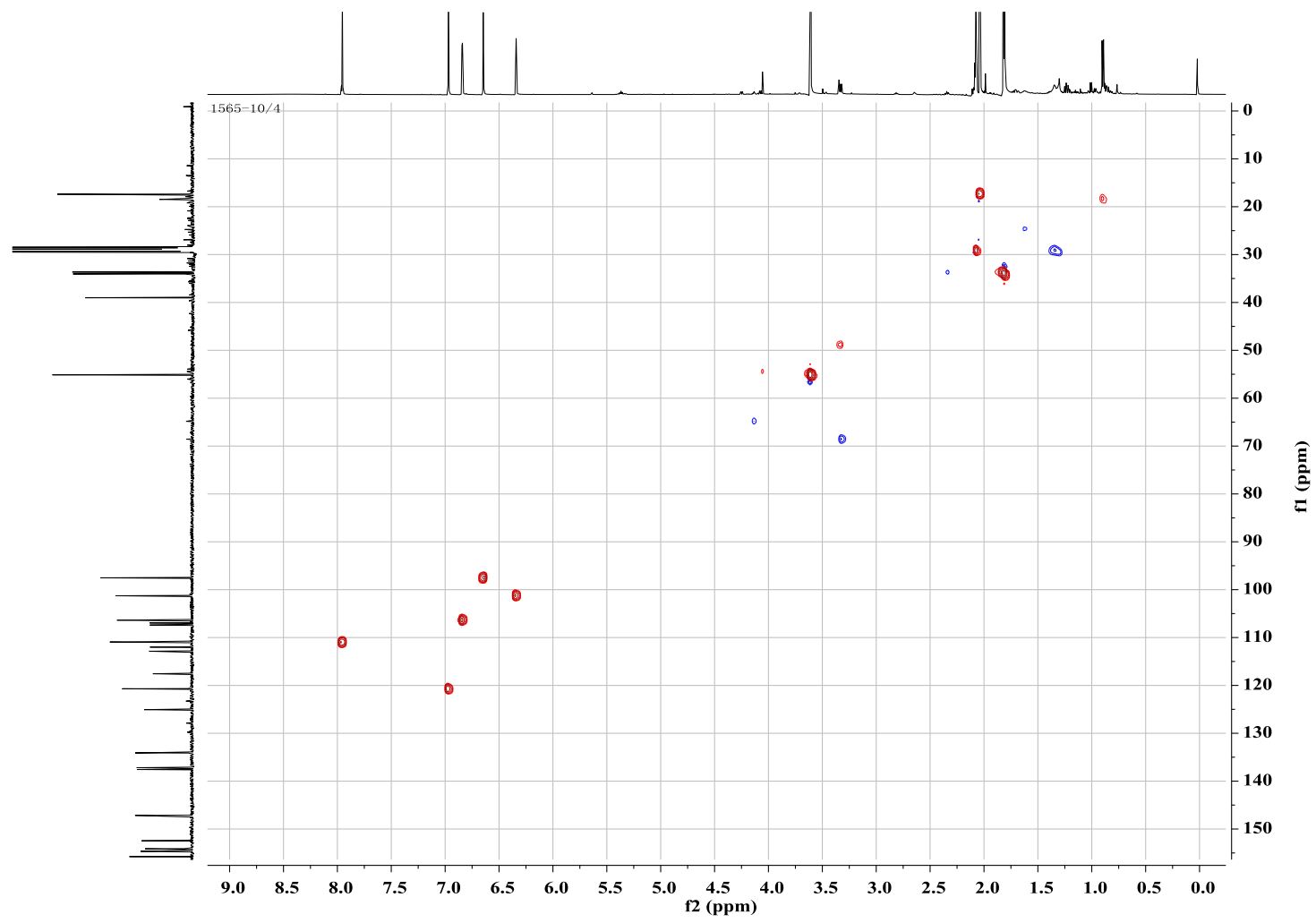

S14 HSQC for compound 3 (500 MHz, Acetone- $d_{6}$ ) 


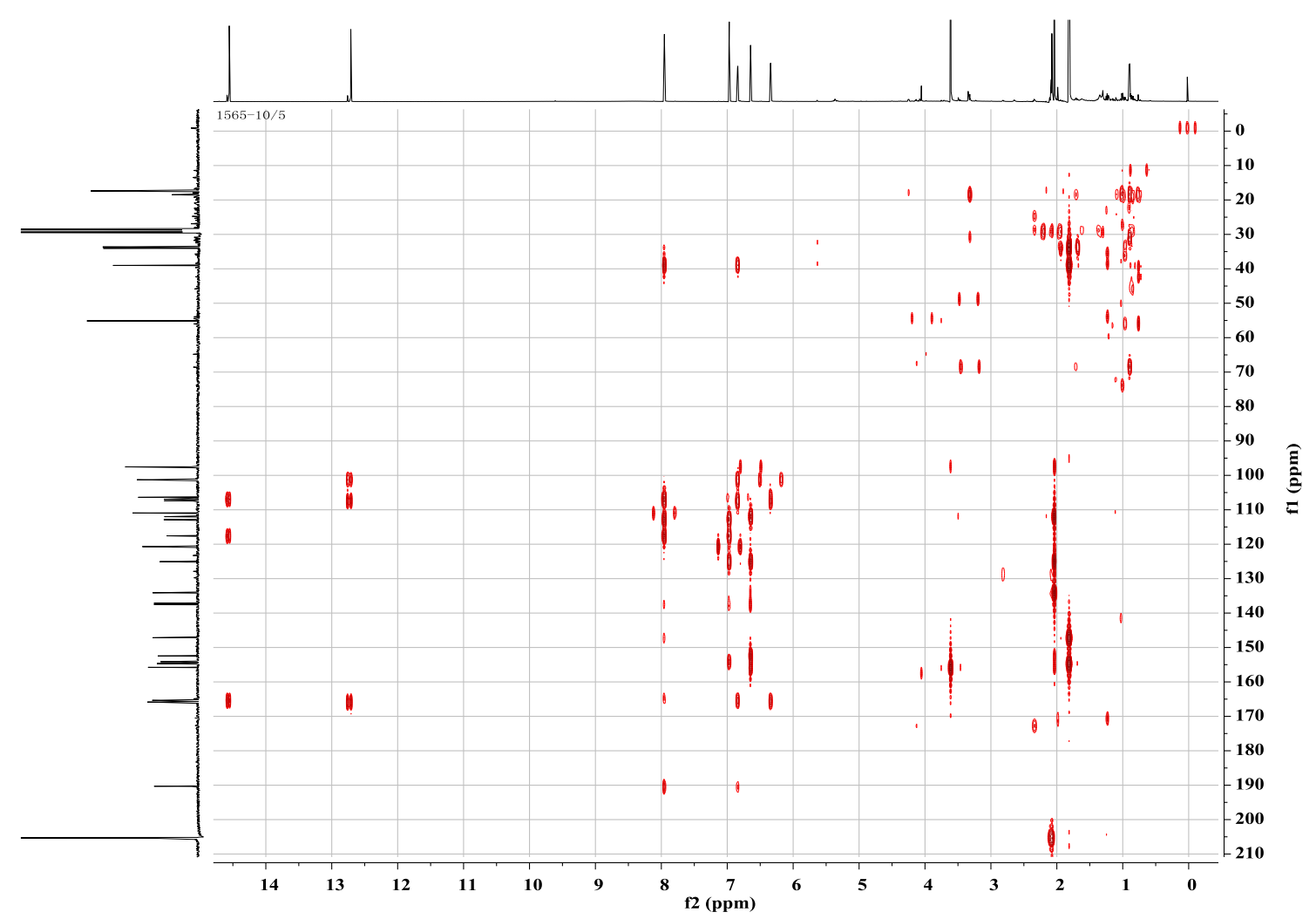

S15 HMBC for compound $3\left(500 \mathrm{MHz}\right.$, Acetone- $\left.d_{6}\right)$

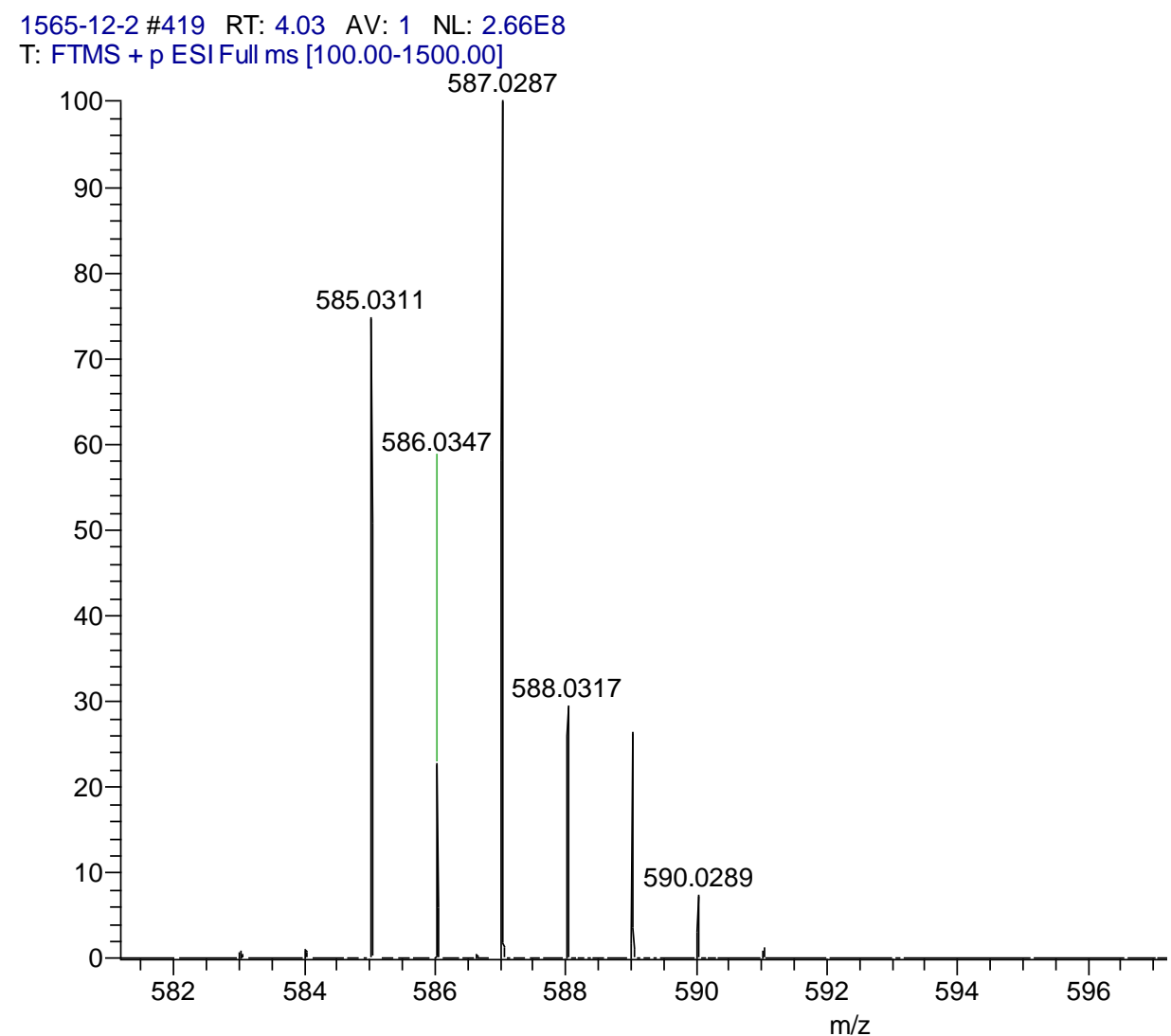

S16 HRESIMS for compound 4 


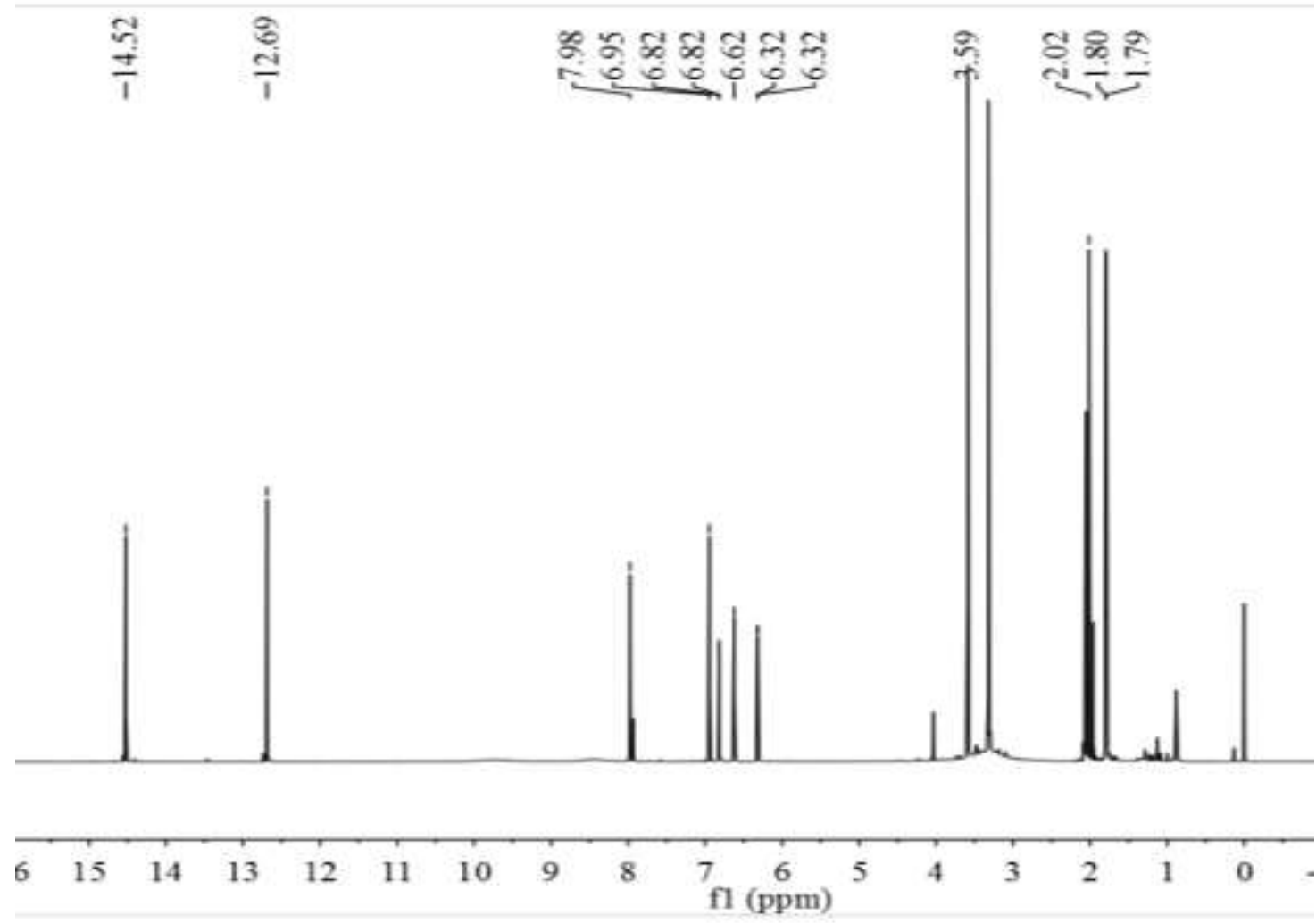

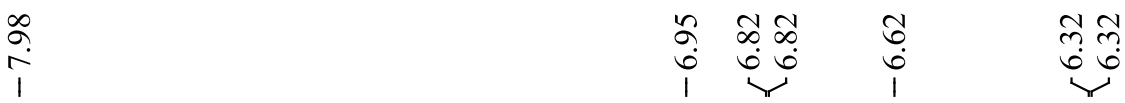
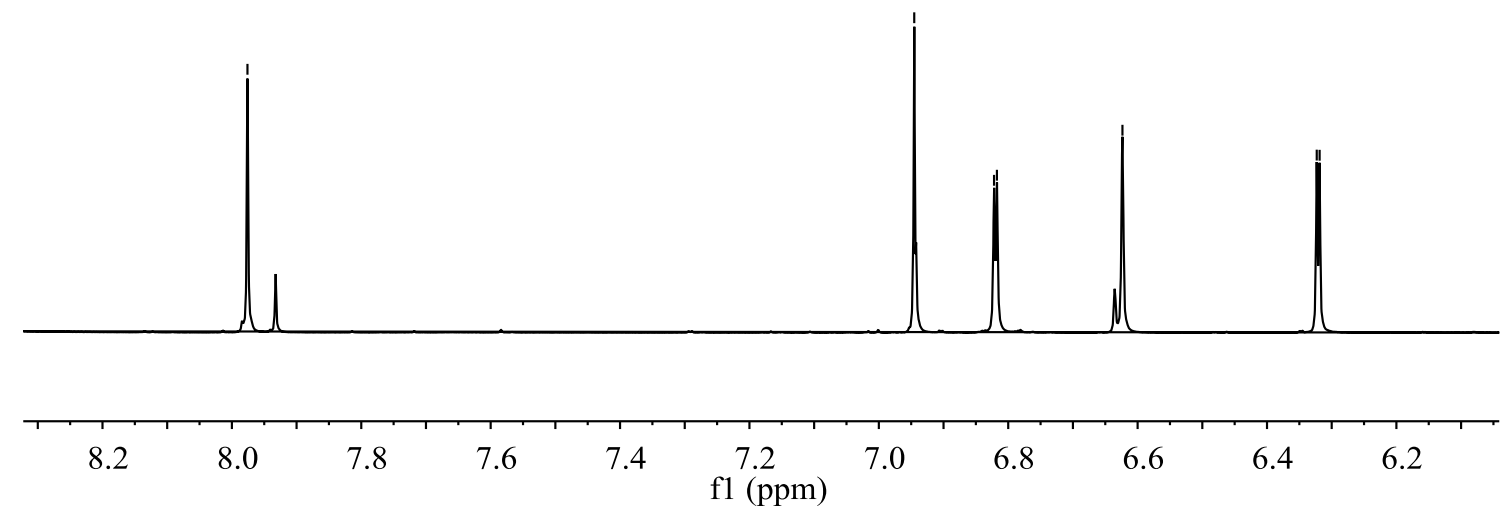

S17 ${ }^{1} \mathrm{H}$ NMR and the expansion spectra of the aromatic region for compound $4\left(500 \mathrm{MHz}\right.$, Acetone- $\left.d_{6}\right)$ 


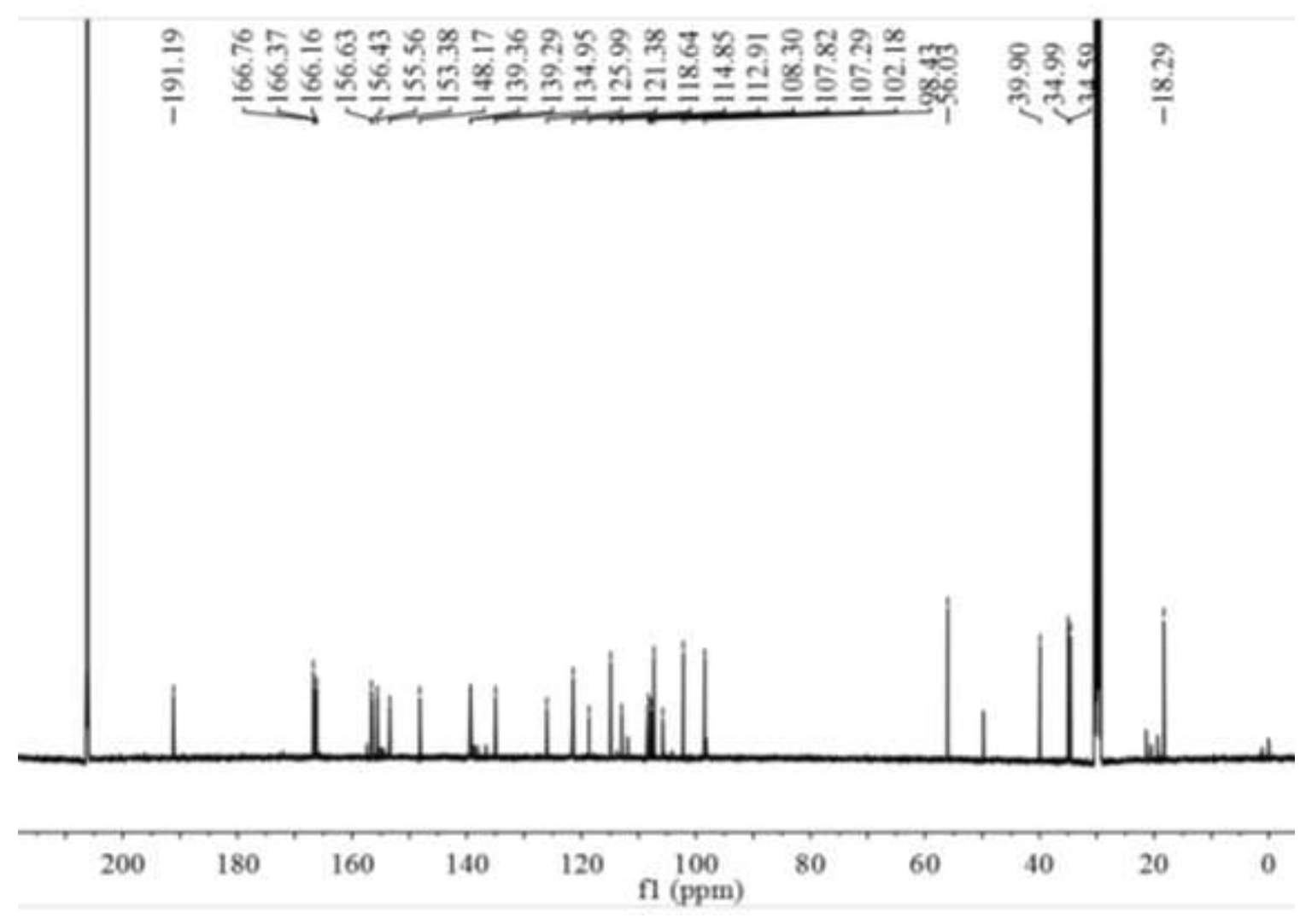

S18 ${ }^{13} \mathrm{C}$ NMR for compound 4 (125 MHz, Acetone- $\left.d_{6}\right)$

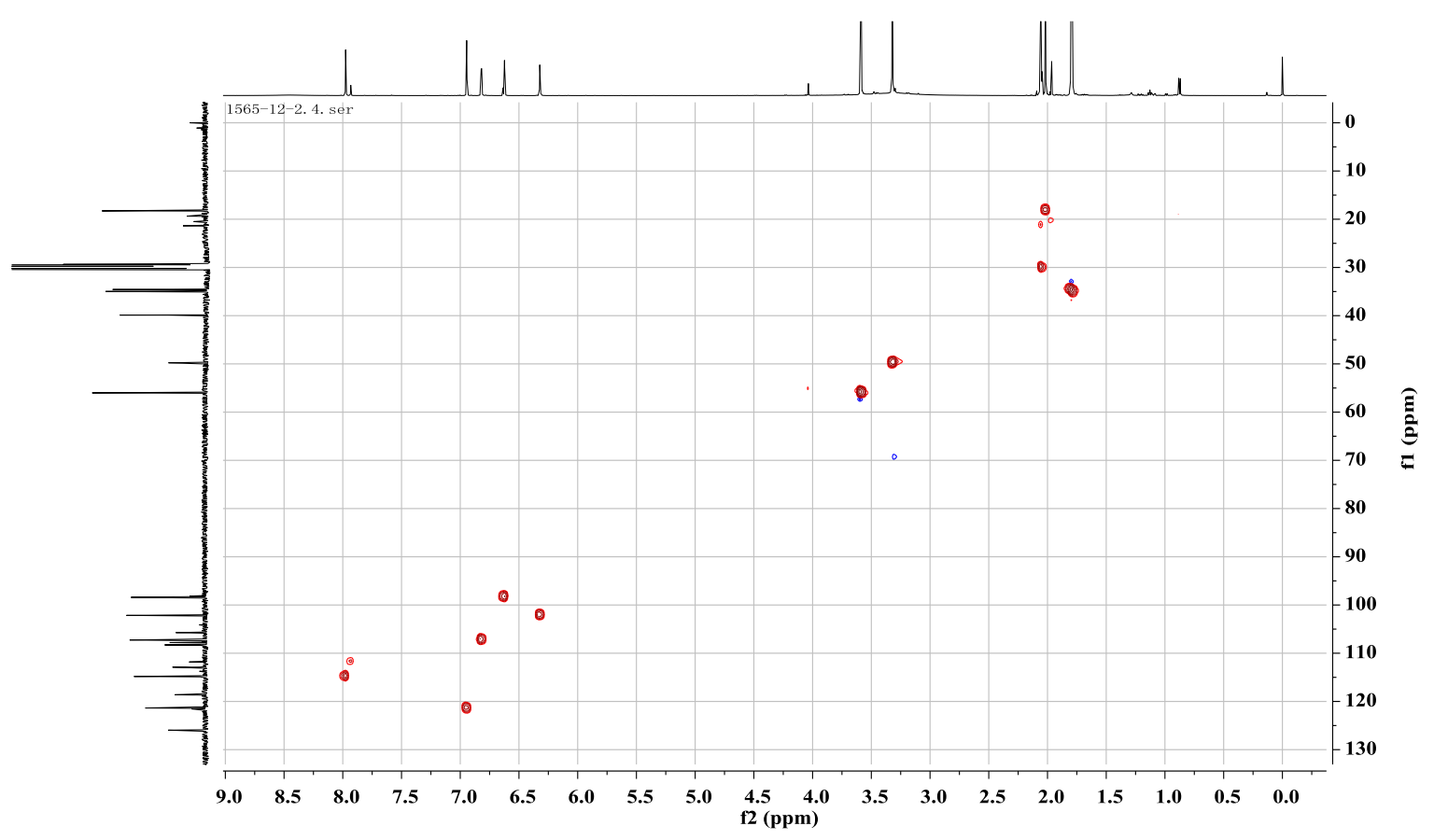

S19 HSQC for compound 4 (500 MHz, Acetone- $d_{6}$ ) 


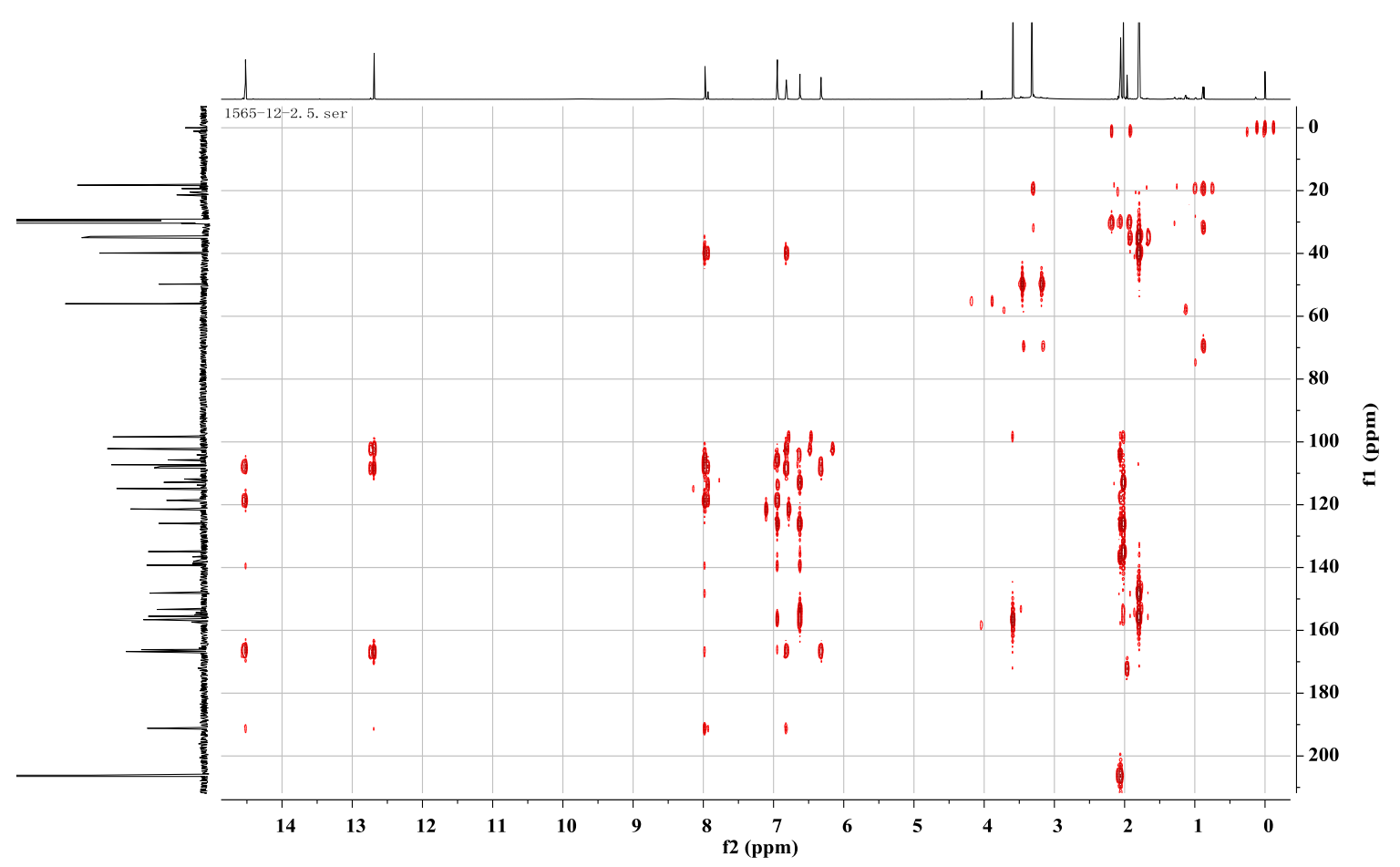

S20 HMBC for compound $4\left(500 \mathrm{MHz}\right.$, Acetone- $\left.d_{6}\right)$

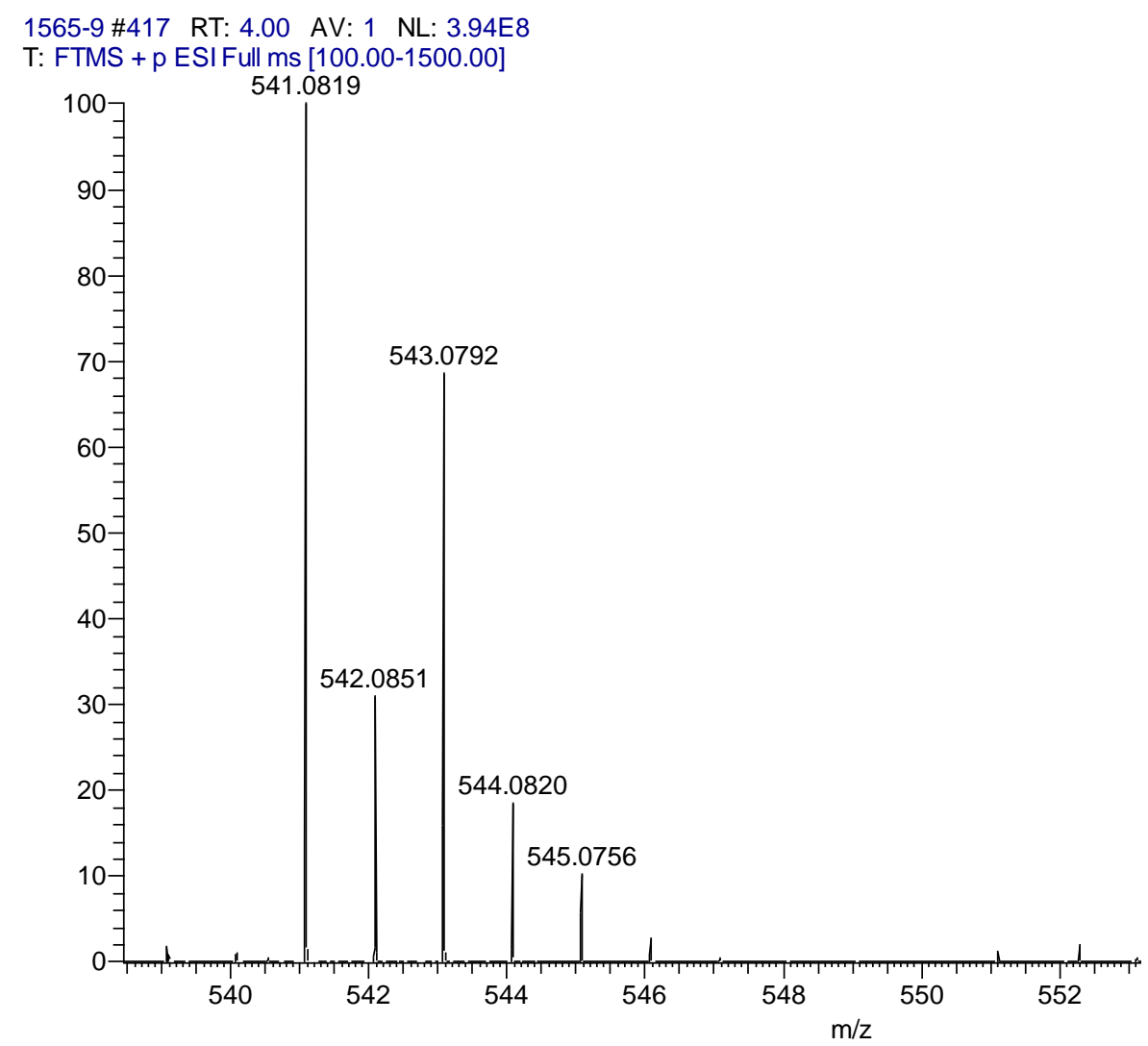

S21 HRESIMS for compound 5 


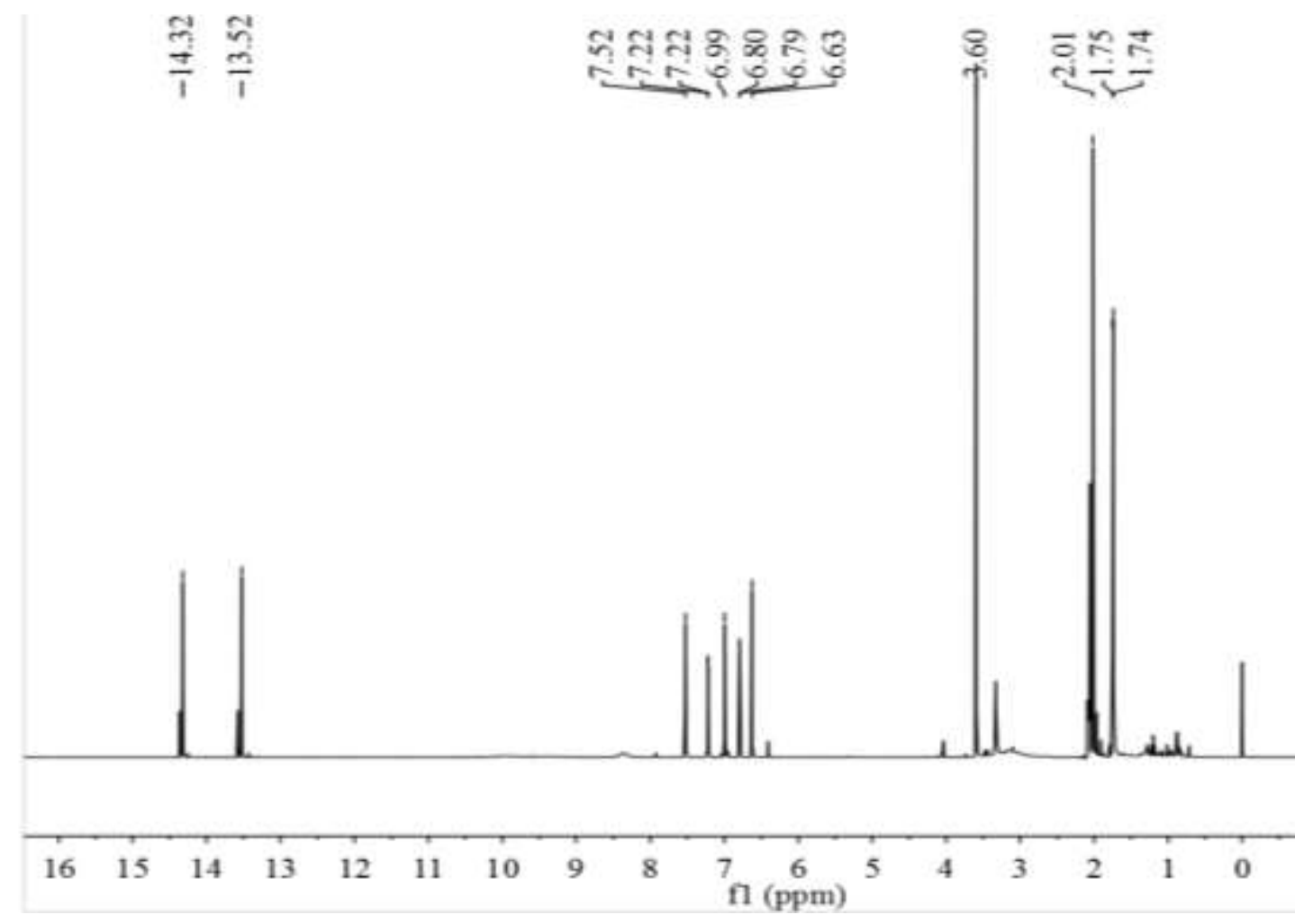

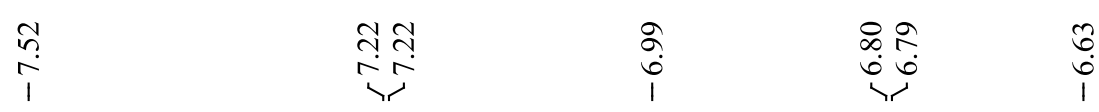

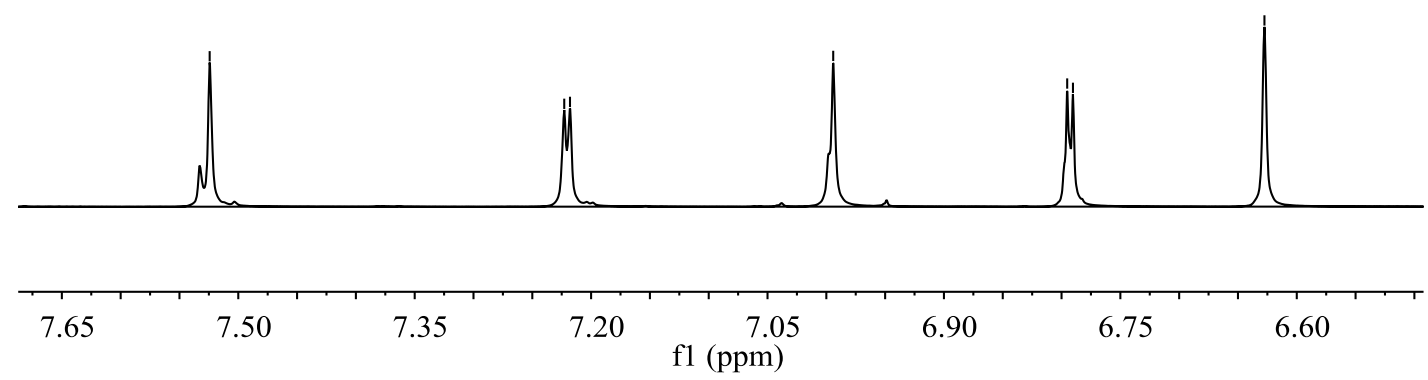

S22 ${ }^{1} \mathrm{H}$ NMR and the expansion spectra of the aromatic region for compound $5\left(500 \mathrm{MHz}\right.$, Acetone- $\left.d_{6}\right)$ 


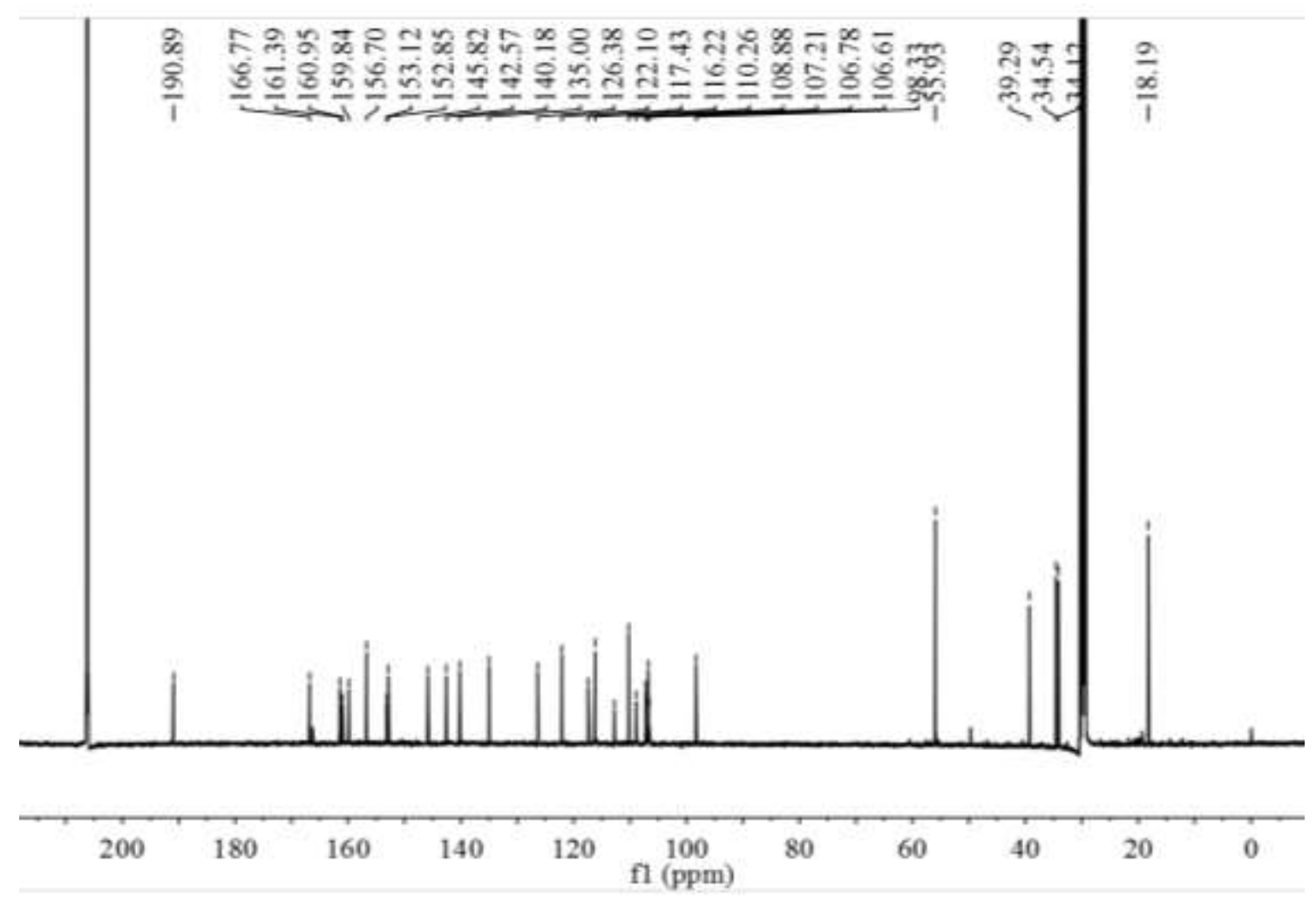

S23 ${ }^{13} \mathrm{C}$ NMR for compound 5 (125 MHz, Acetone- $\left.d_{6}\right)$

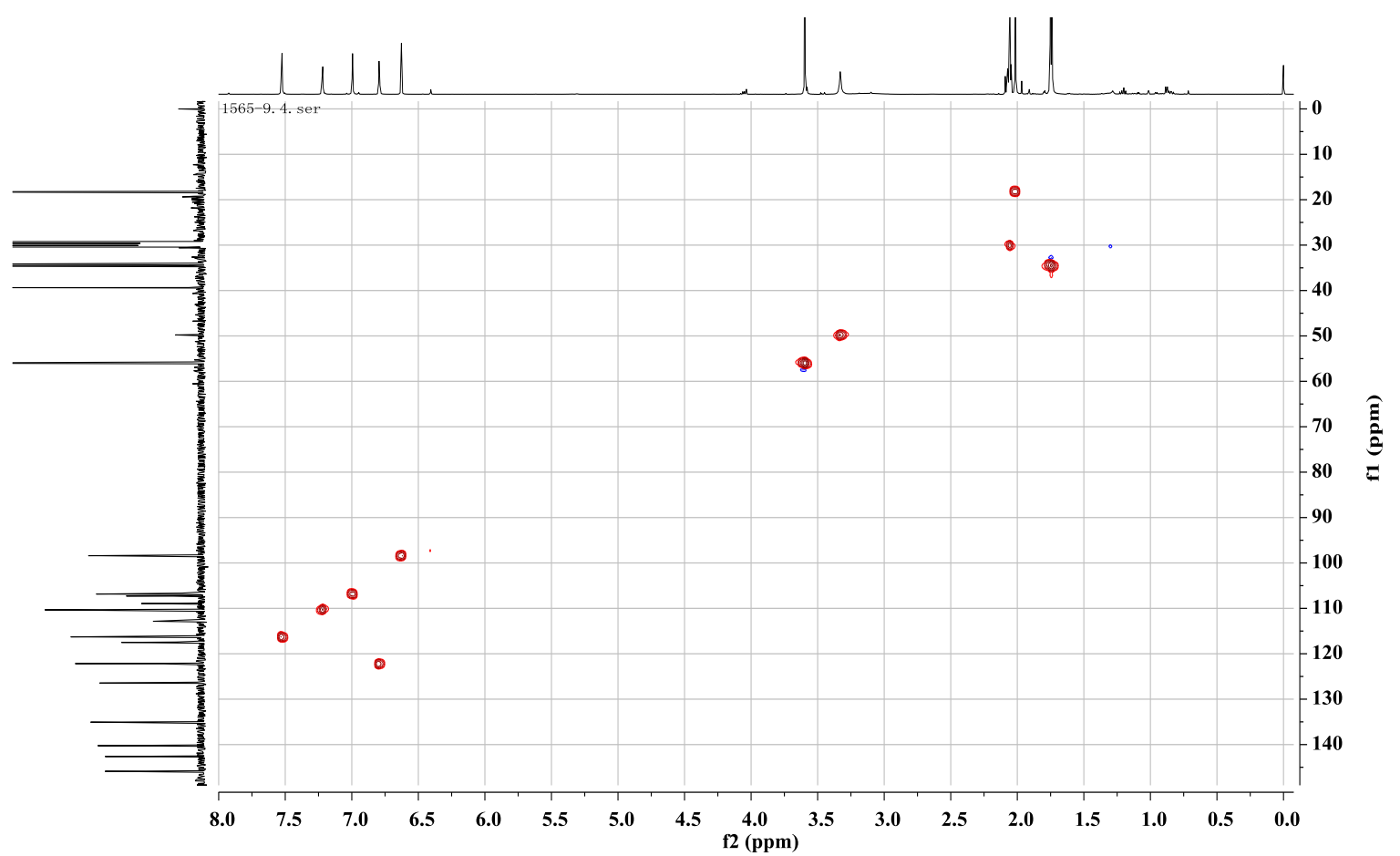

S24 HSQC for compound 5 (500 MHz, Acetone- $d_{6}$ ) 


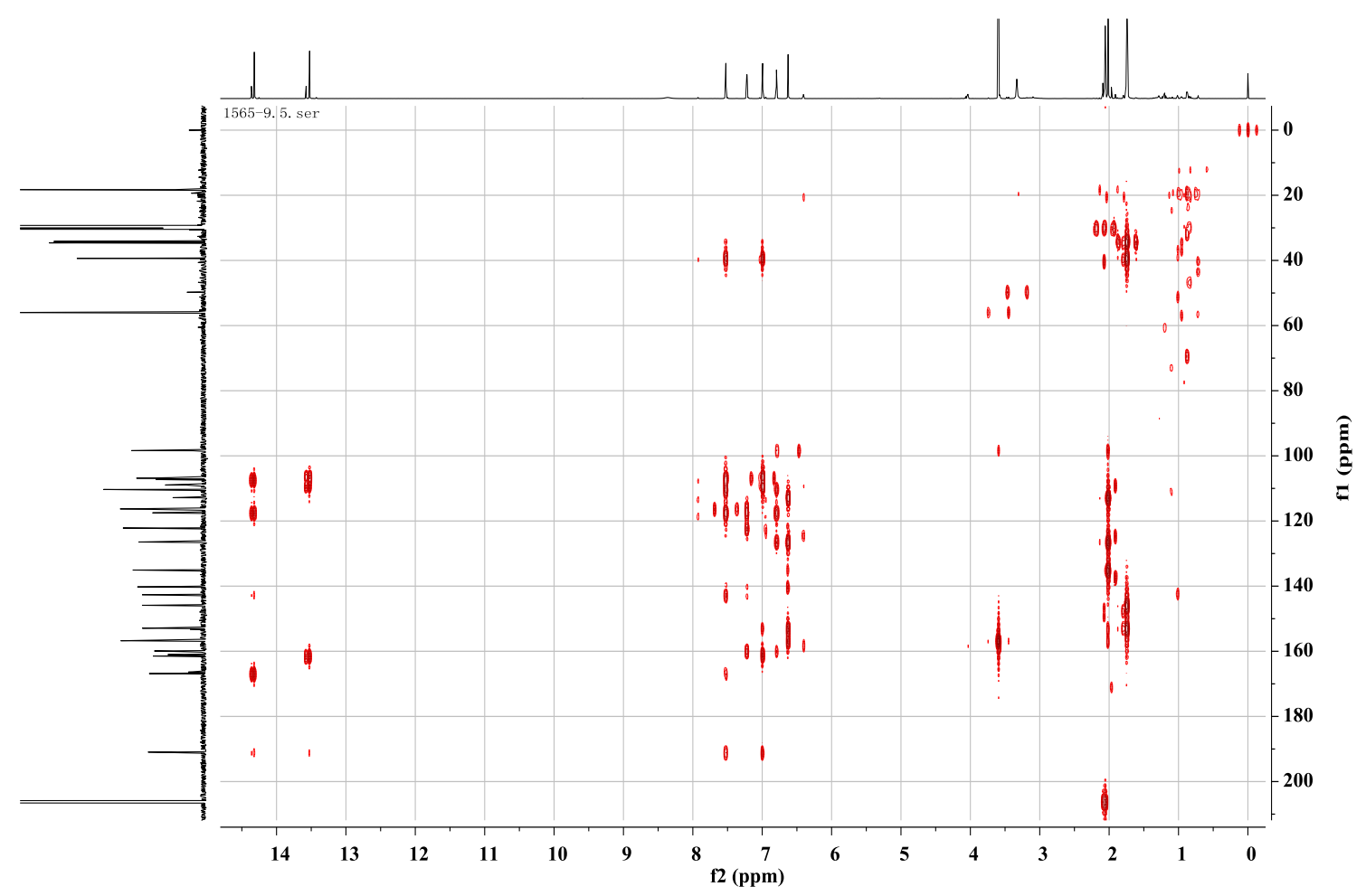

S25 HMBC for compound 5 (500 MHz, Acetone- $d_{6}$ )

1565-12 \#443 RT: 4.26 AV: 1 NL: $6.11 E 7$

T: FTMS + p ESI Full ms [100.00-1500.00]

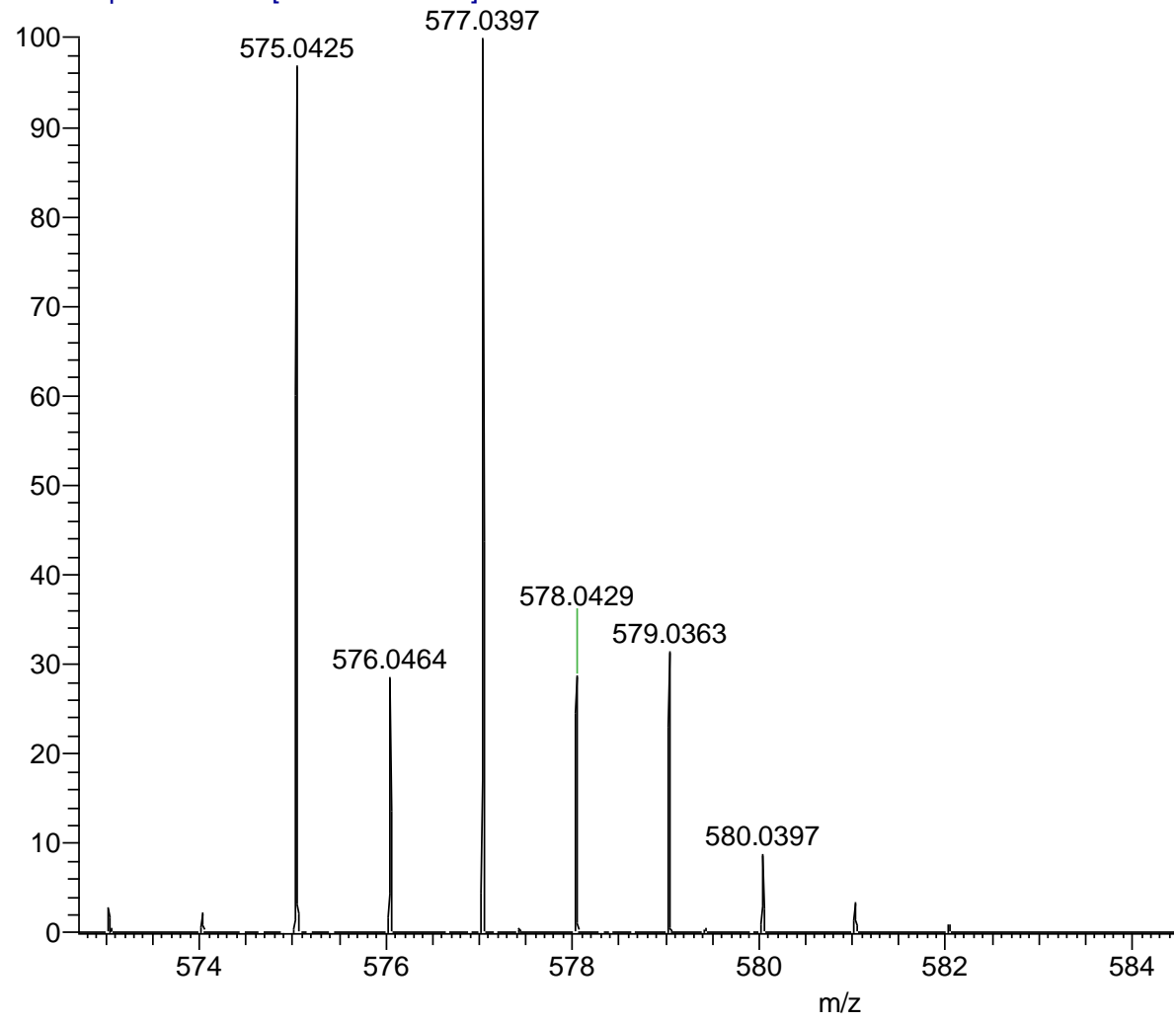

S26 HRESIMS for compound 6 

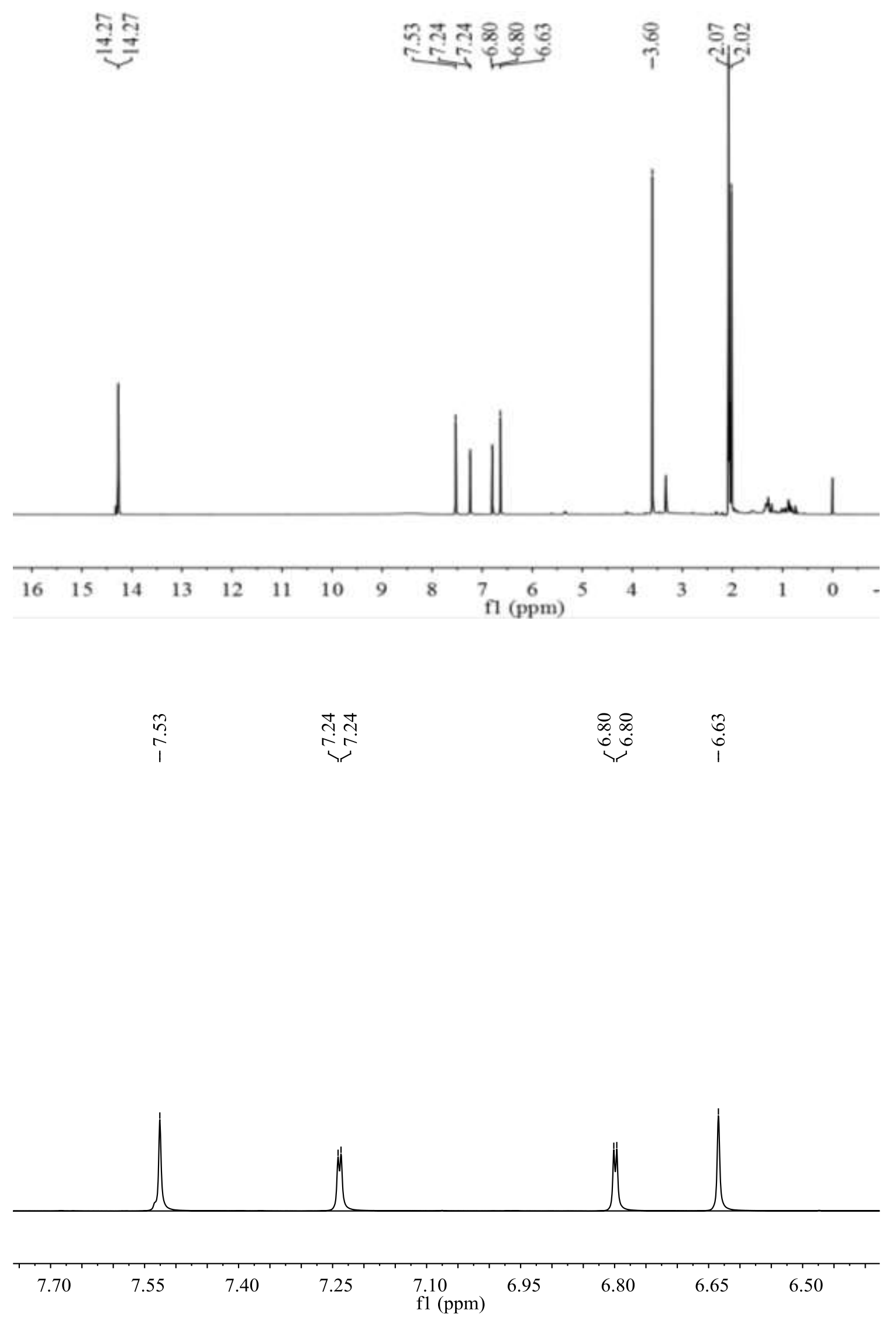

S27 ${ }^{1} \mathrm{H}$ NMR and the expansion spectra of the aromatic region for compound $6\left(500 \mathrm{MHz}\right.$, Acetone- $\left.d_{6}\right)$ 


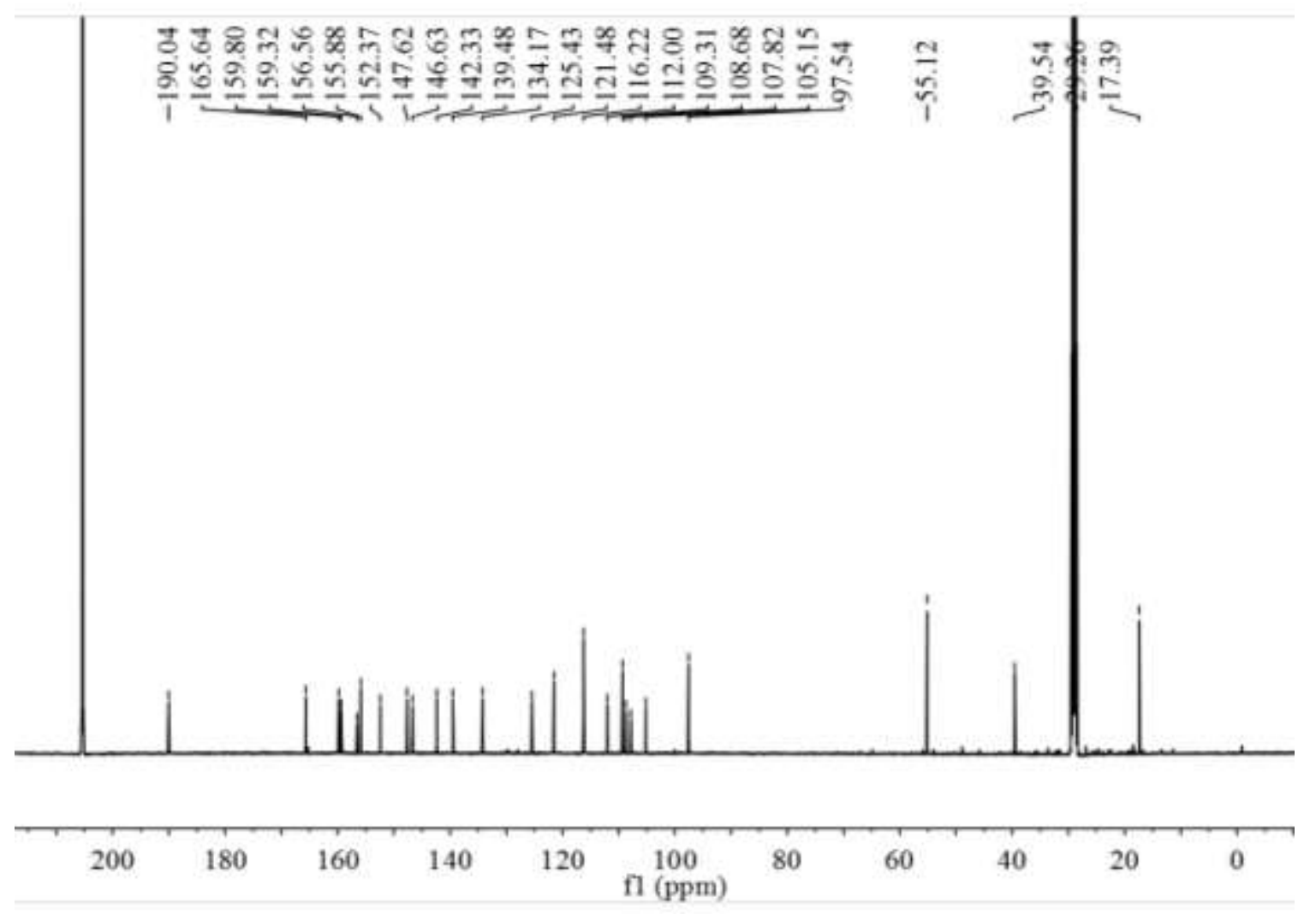

S28 ${ }^{13} \mathrm{C}$ NMR for compound $6\left(125 \mathrm{MHz}\right.$, Acetone- $\left.d_{6}\right)$

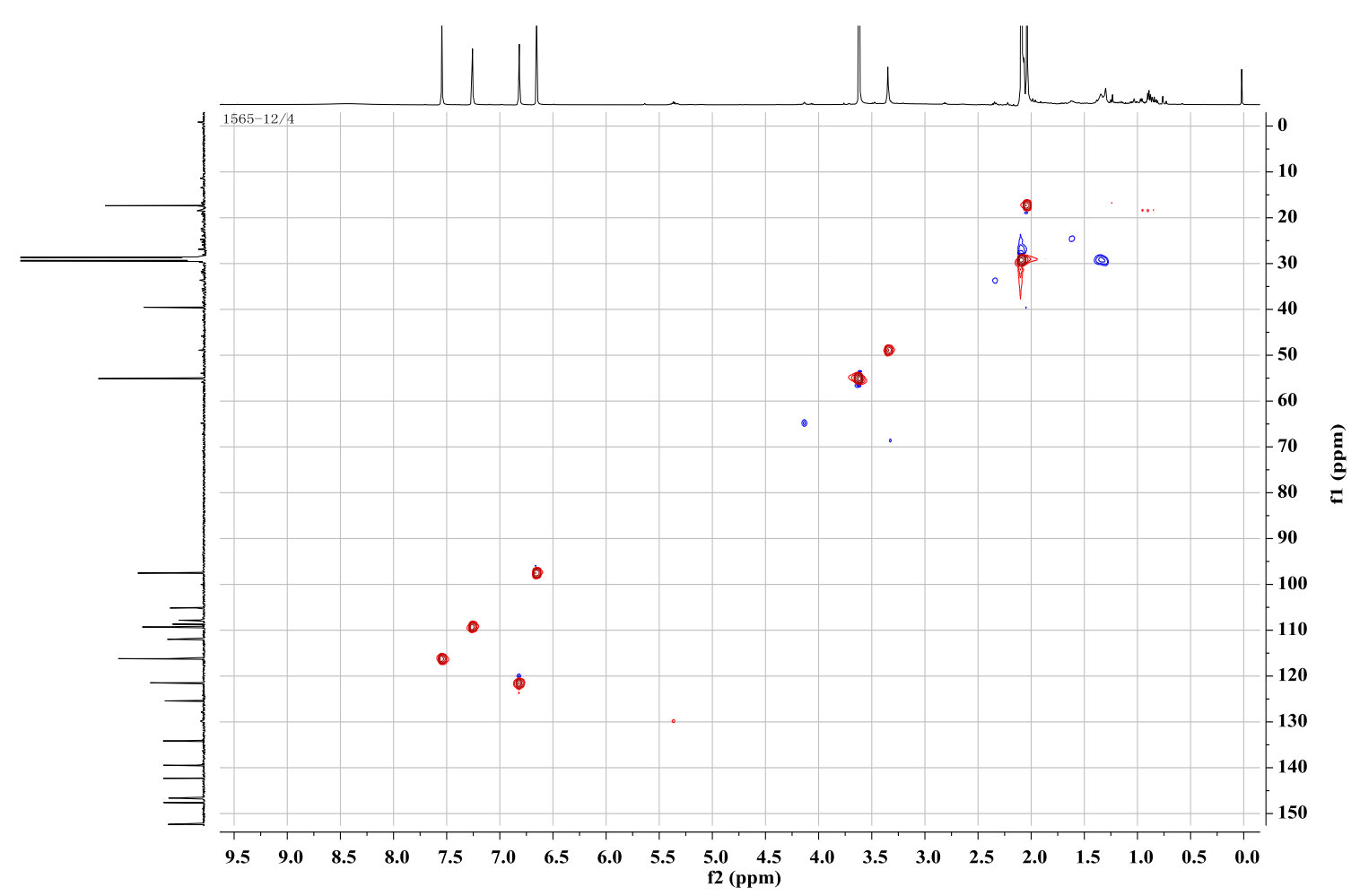

S29 HSQC for compound 6 (500 MHz, Acetone- $d_{6}$ ) 


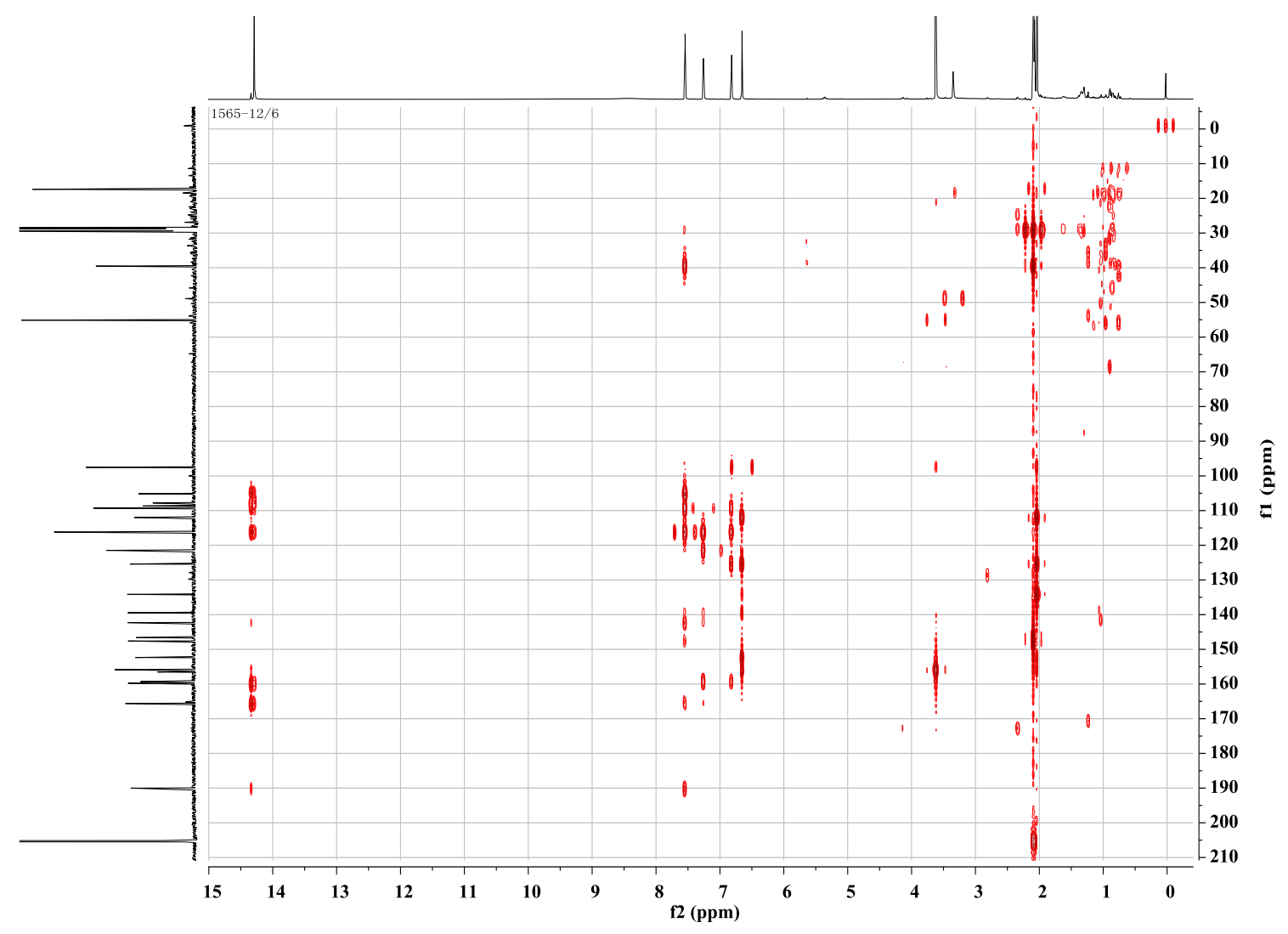

S30 HMBC for compound $6\left(500 \mathrm{MHz}\right.$, Acetone- $\left.d_{6}\right)$

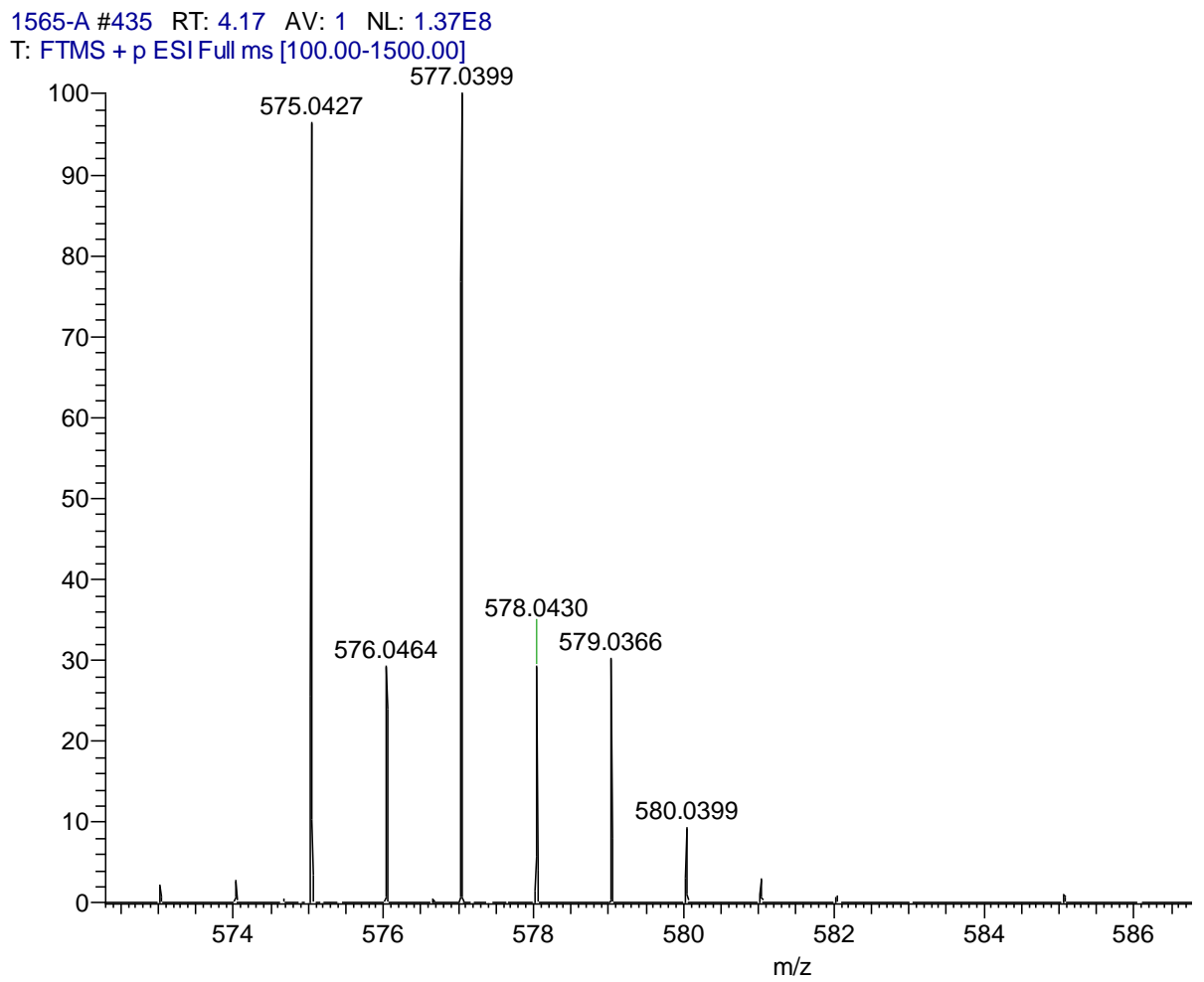

S31 HRESIMS for compound 7 

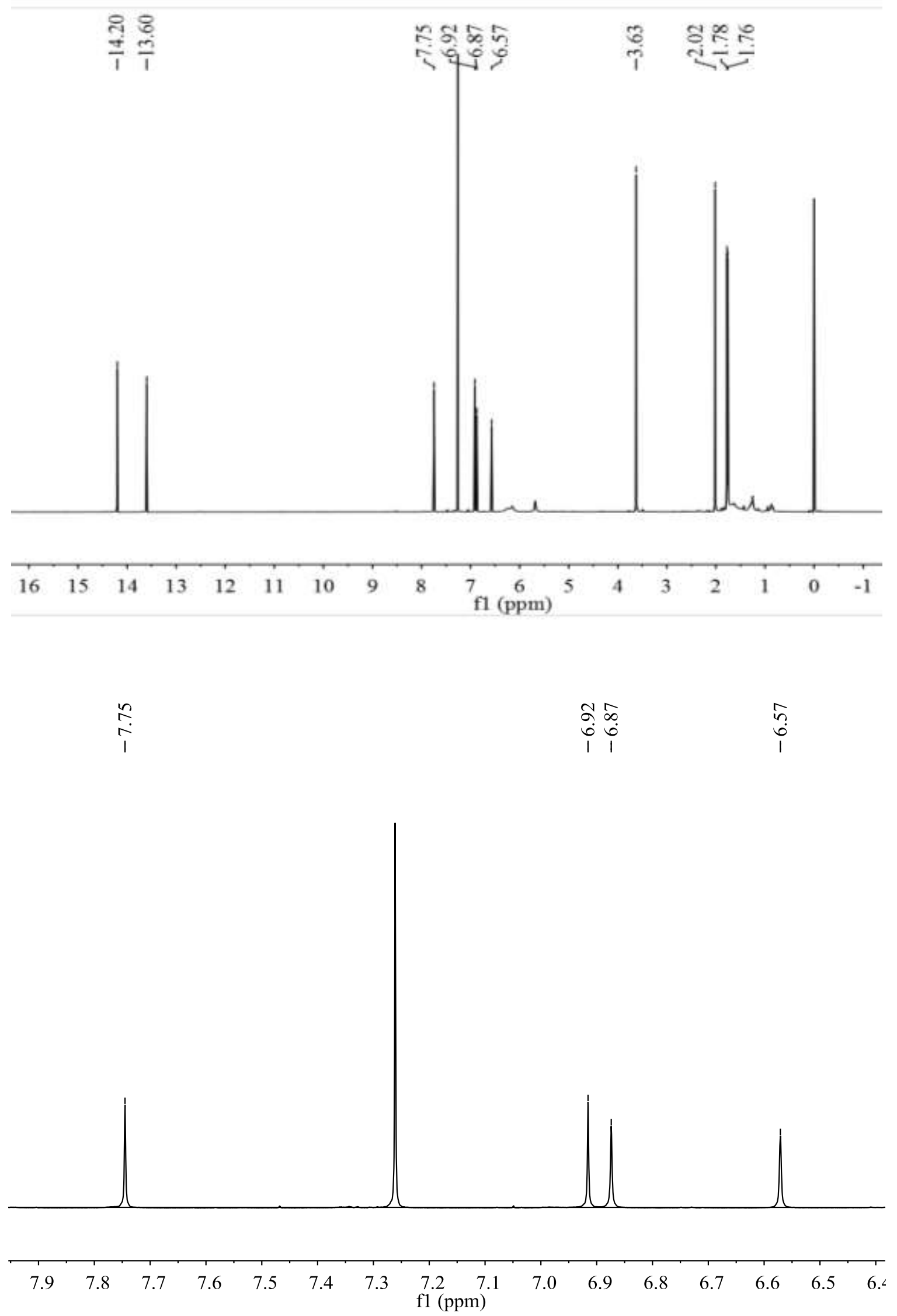

S32 ${ }^{1} \mathrm{H}$ NMR and the expansion spectra of the aromatic region for compound $7\left(500 \mathrm{MHz}, \mathrm{CDCl}_{3}\right)$ 


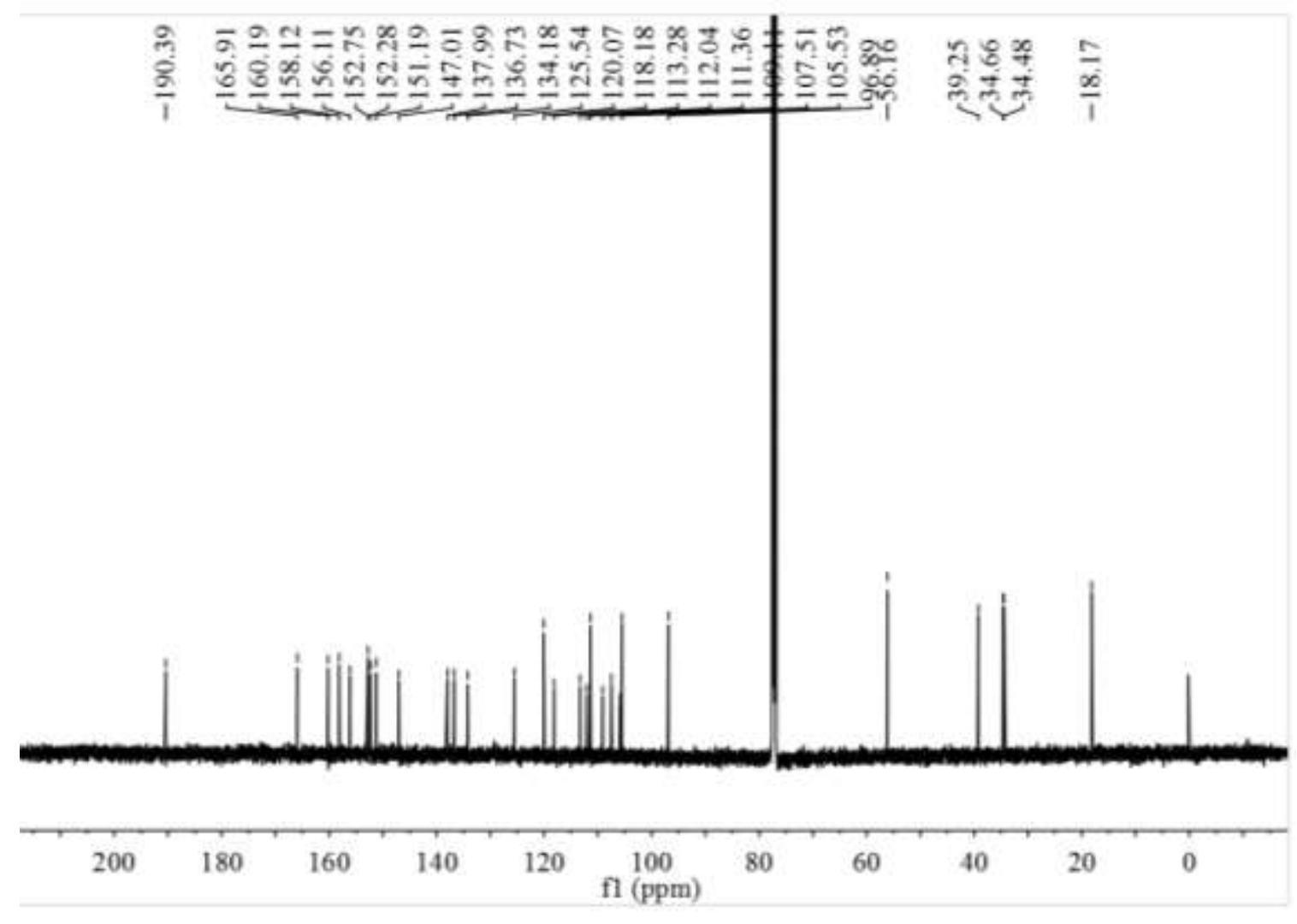

S33 ${ }^{13} \mathrm{C}$ NMR for compound $7\left(125 \mathrm{MHz}, \mathrm{CDCl}_{3}\right)$

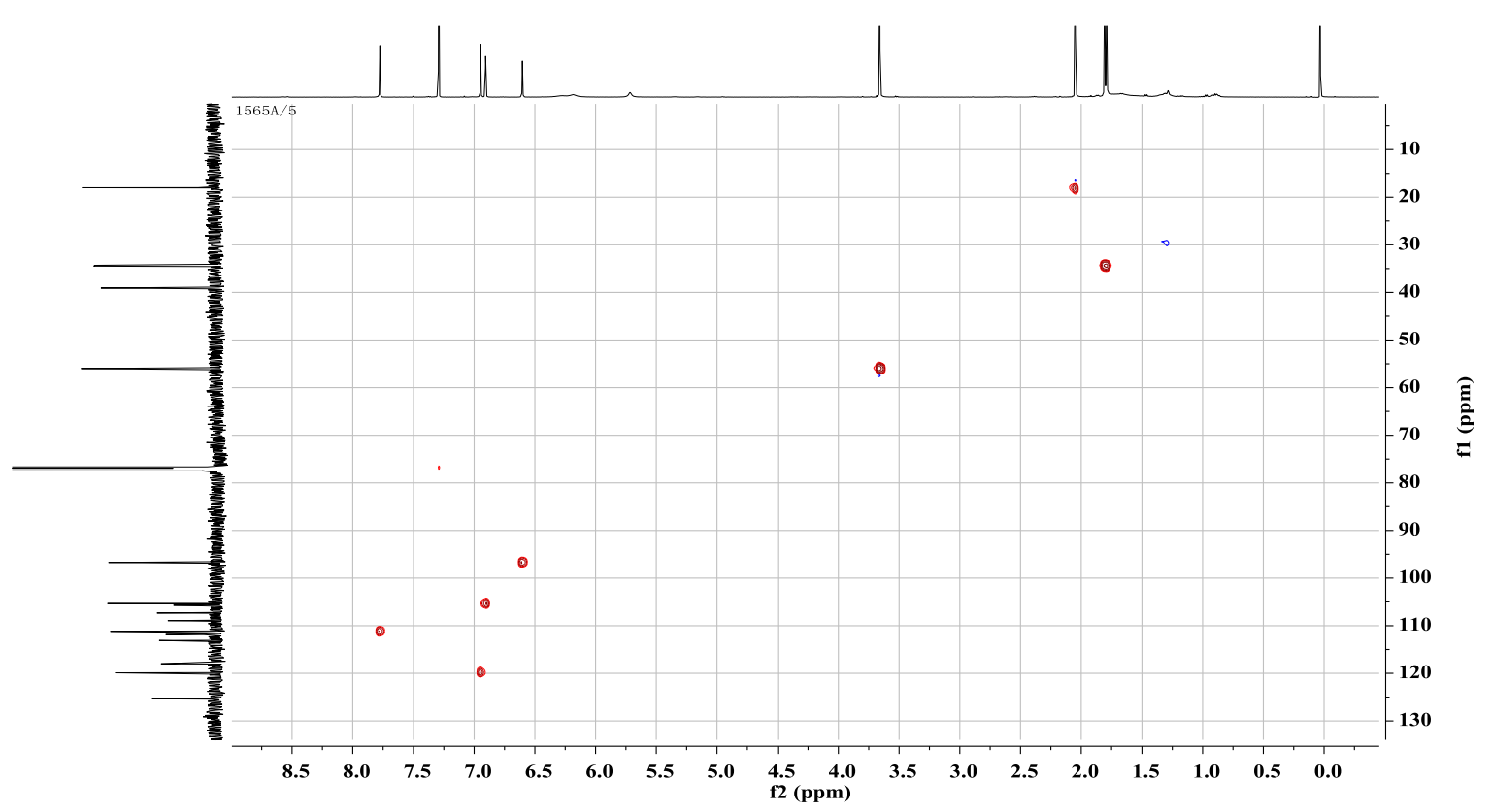

S34 HSQC for compound $7\left(500 \mathrm{MHz}, \mathrm{CDCl}_{3}\right)$ 


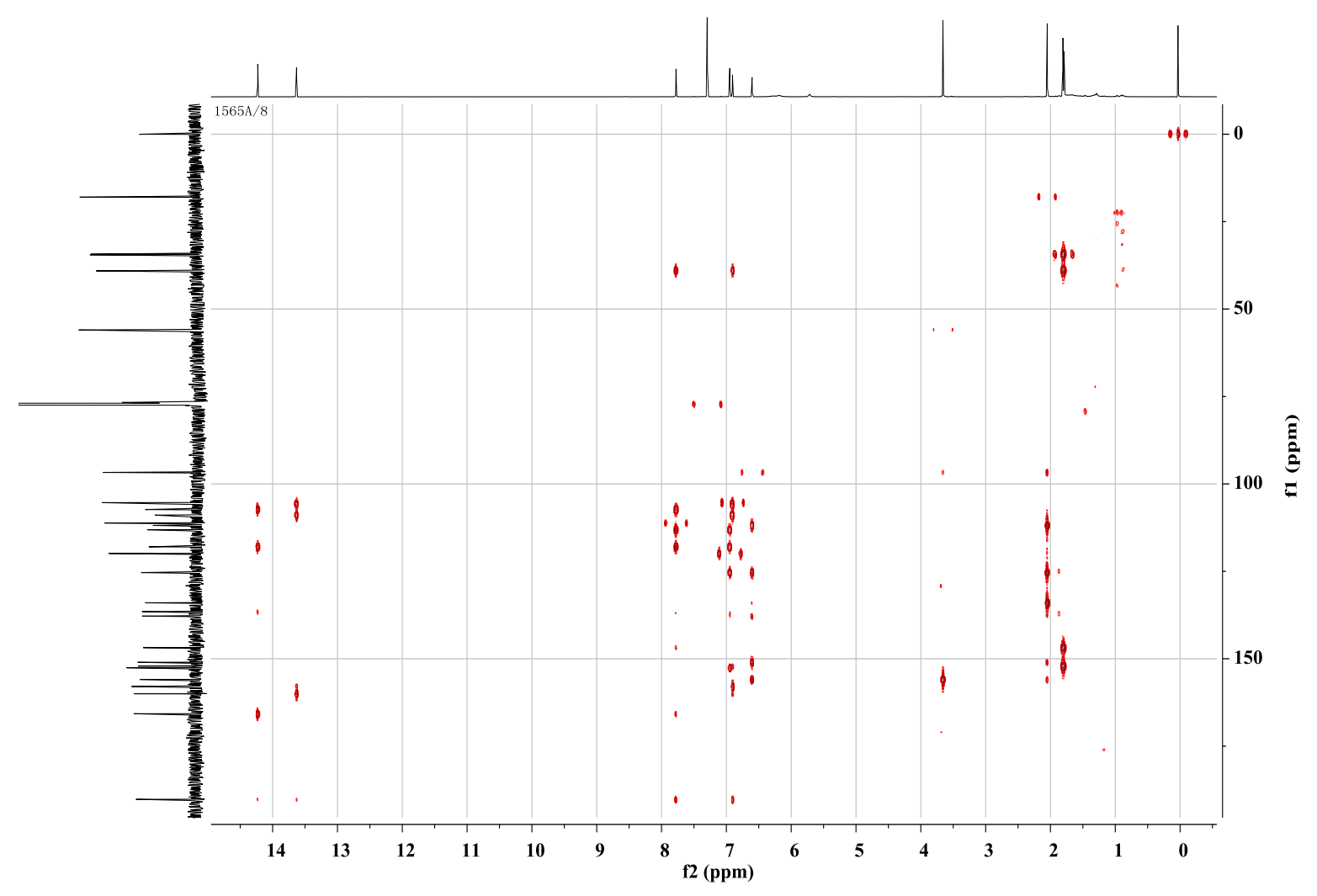

S35 HMBC for compound $7\left(500 \mathrm{MHz}, \mathrm{CDCl}_{3}\right)$

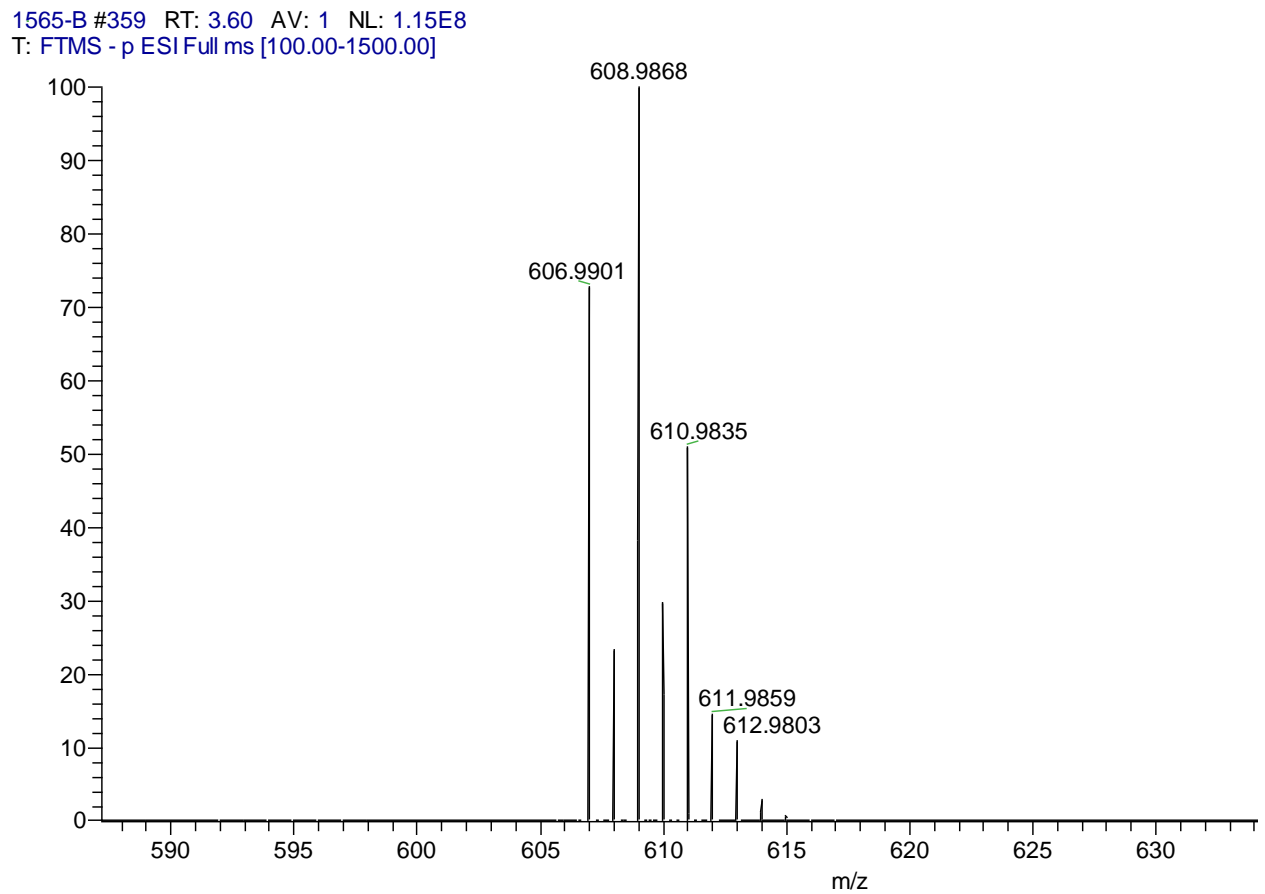

S36 HRESIMS for compound 8 

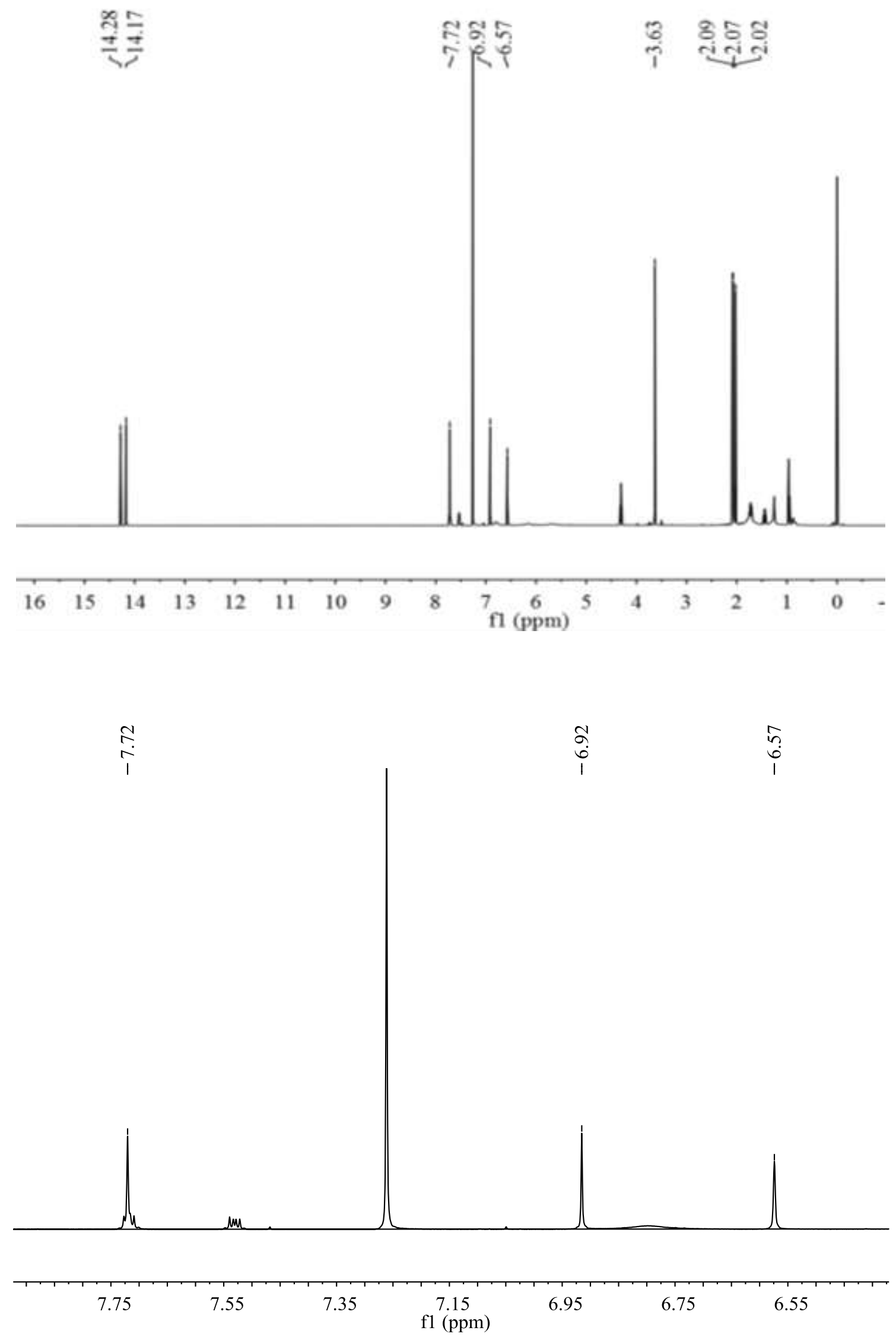

S37 ${ }^{1} \mathrm{H}$ NMR and the expansion spectra of the aromatic region for compound $8\left(500 \mathrm{MHz}, \mathrm{CDCl}_{3}\right)$ 


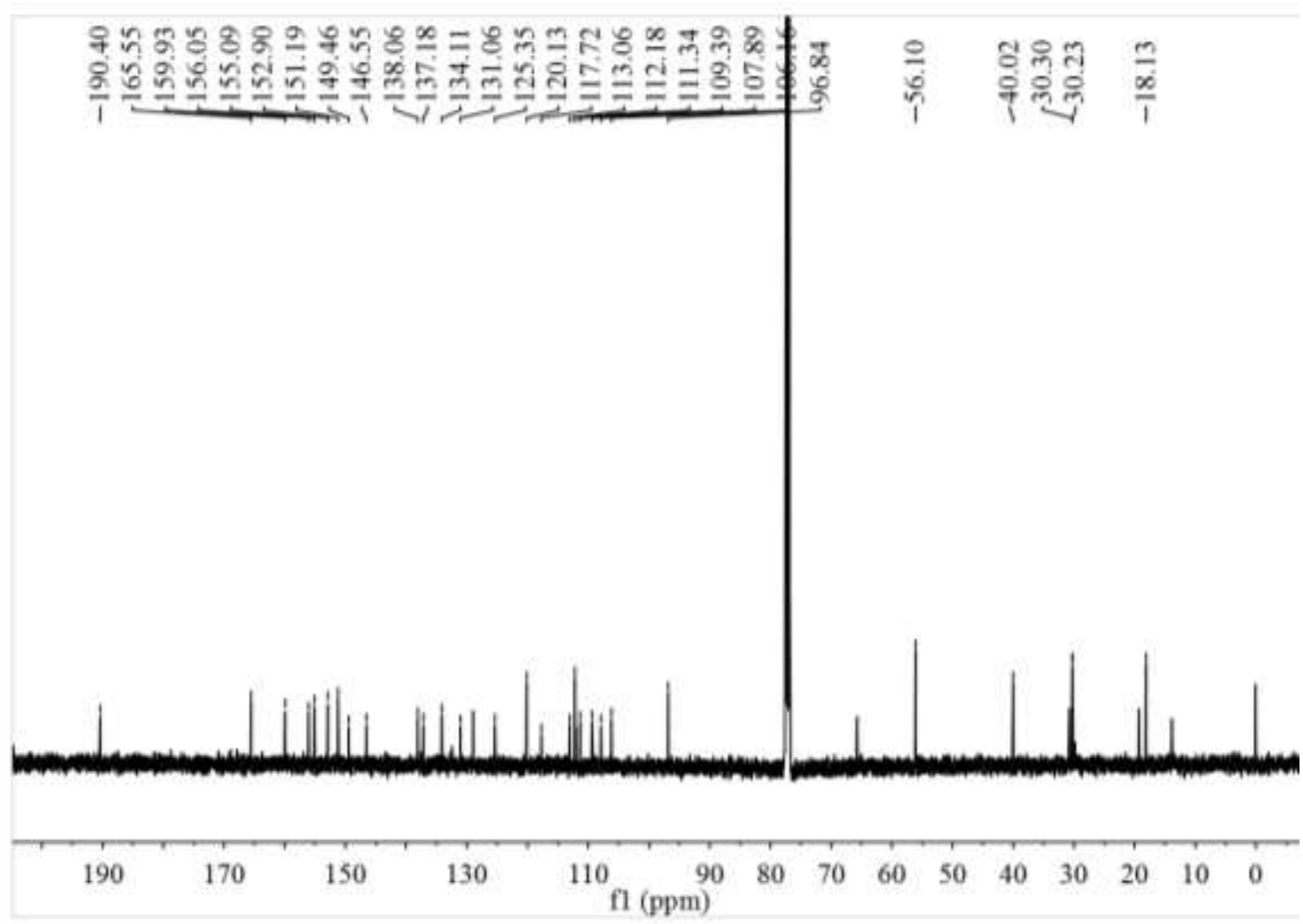

S38 ${ }^{13} \mathrm{C}$ NMR for compound $8\left(125 \mathrm{MHz}, \mathrm{CDCl}_{3}\right)$

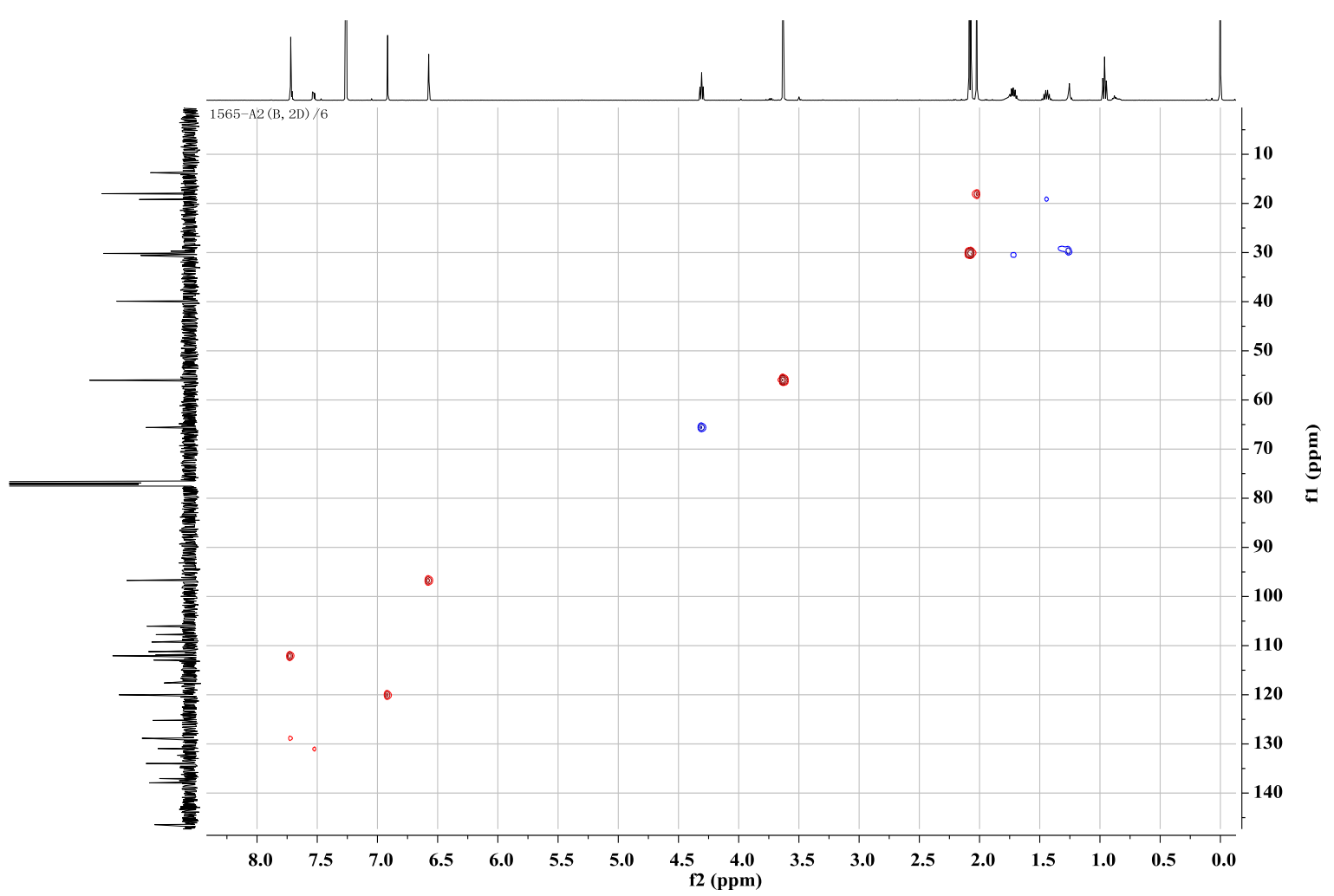

S39 HSQC for compound $8\left(500 \mathrm{MHz}, \mathrm{CDCl}_{3}\right)$ 


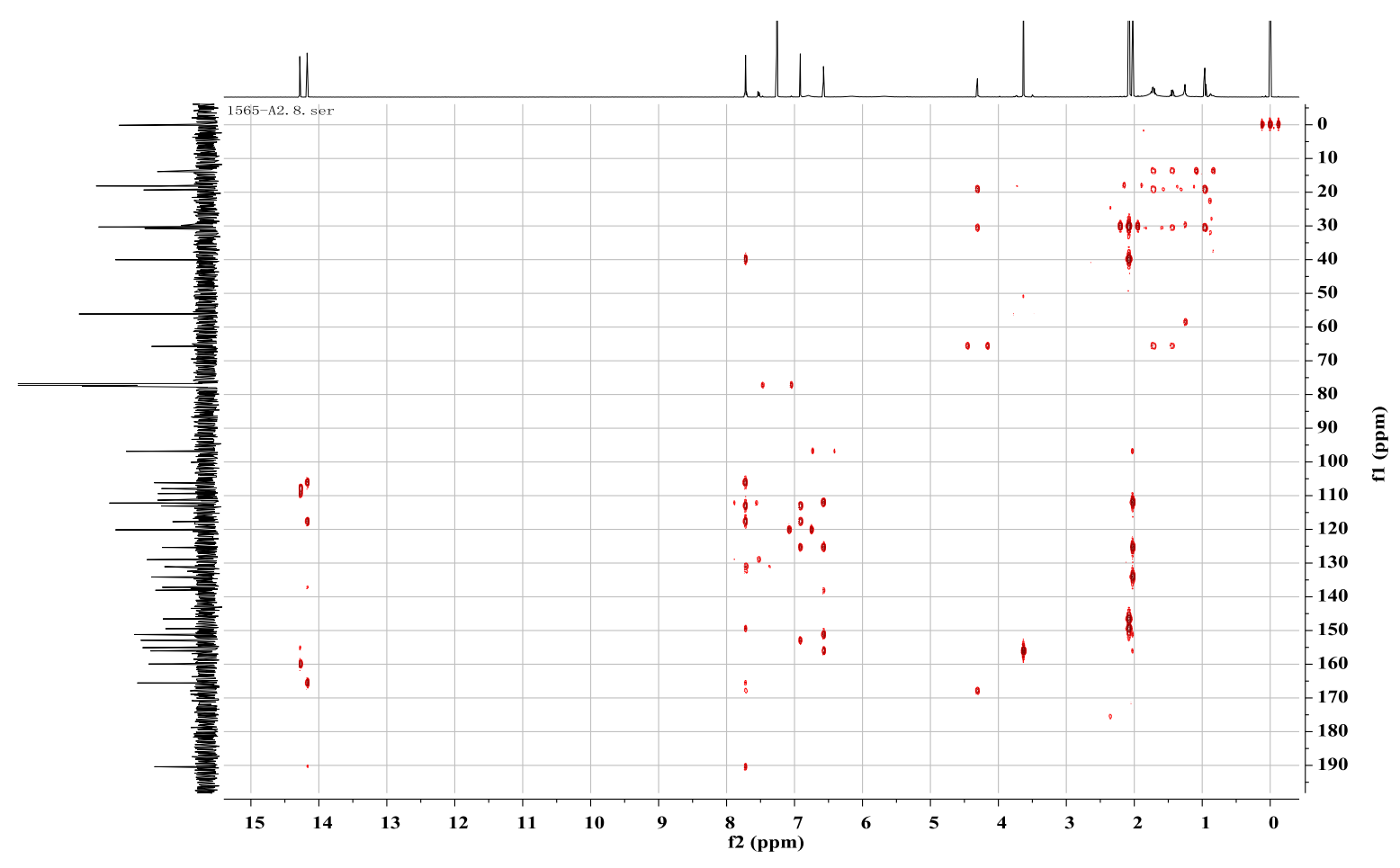

S40 HMBC for compound $8\left(500 \mathrm{MHz}, \mathrm{CDCl}_{3}\right)$

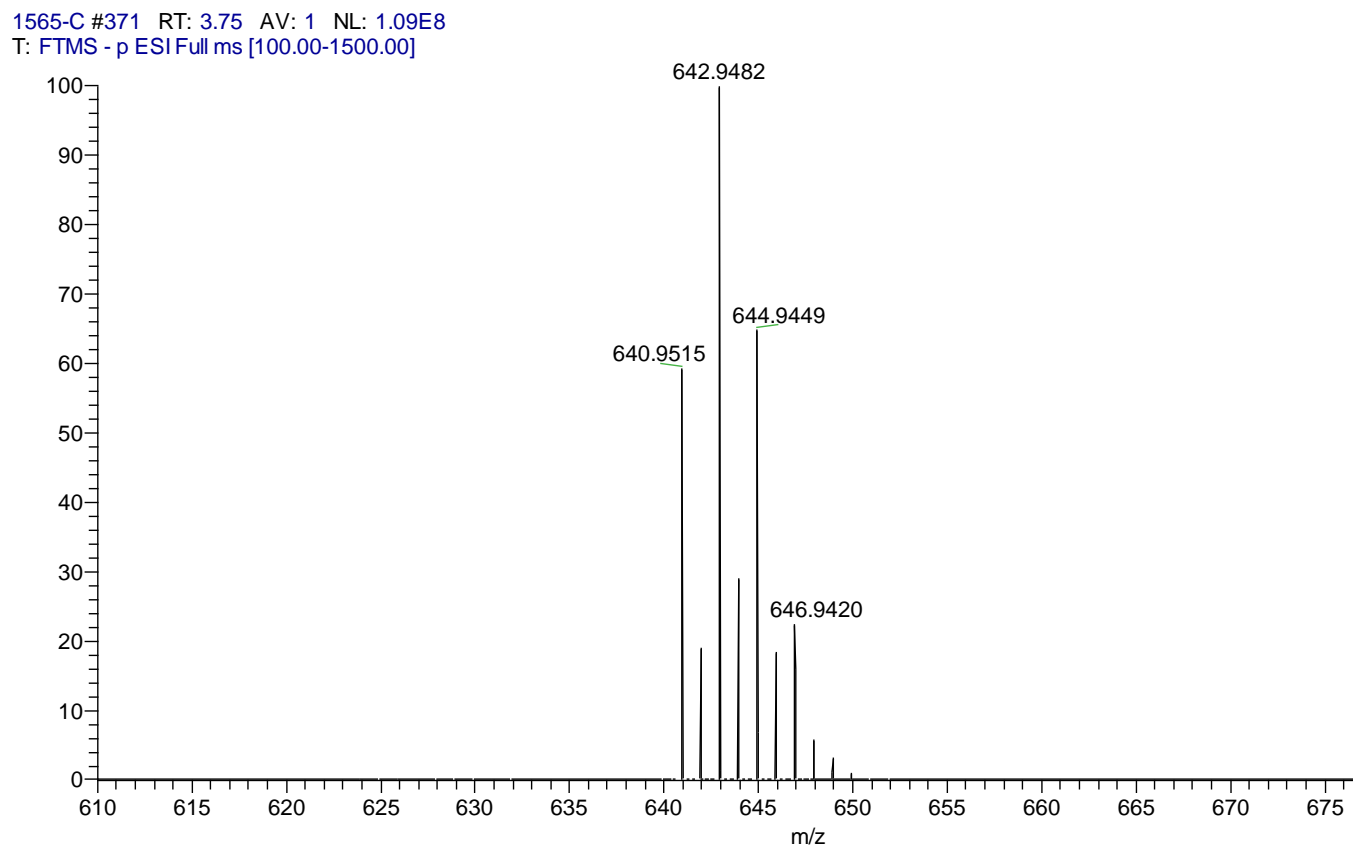

S41 HRESIMS for compound 9 

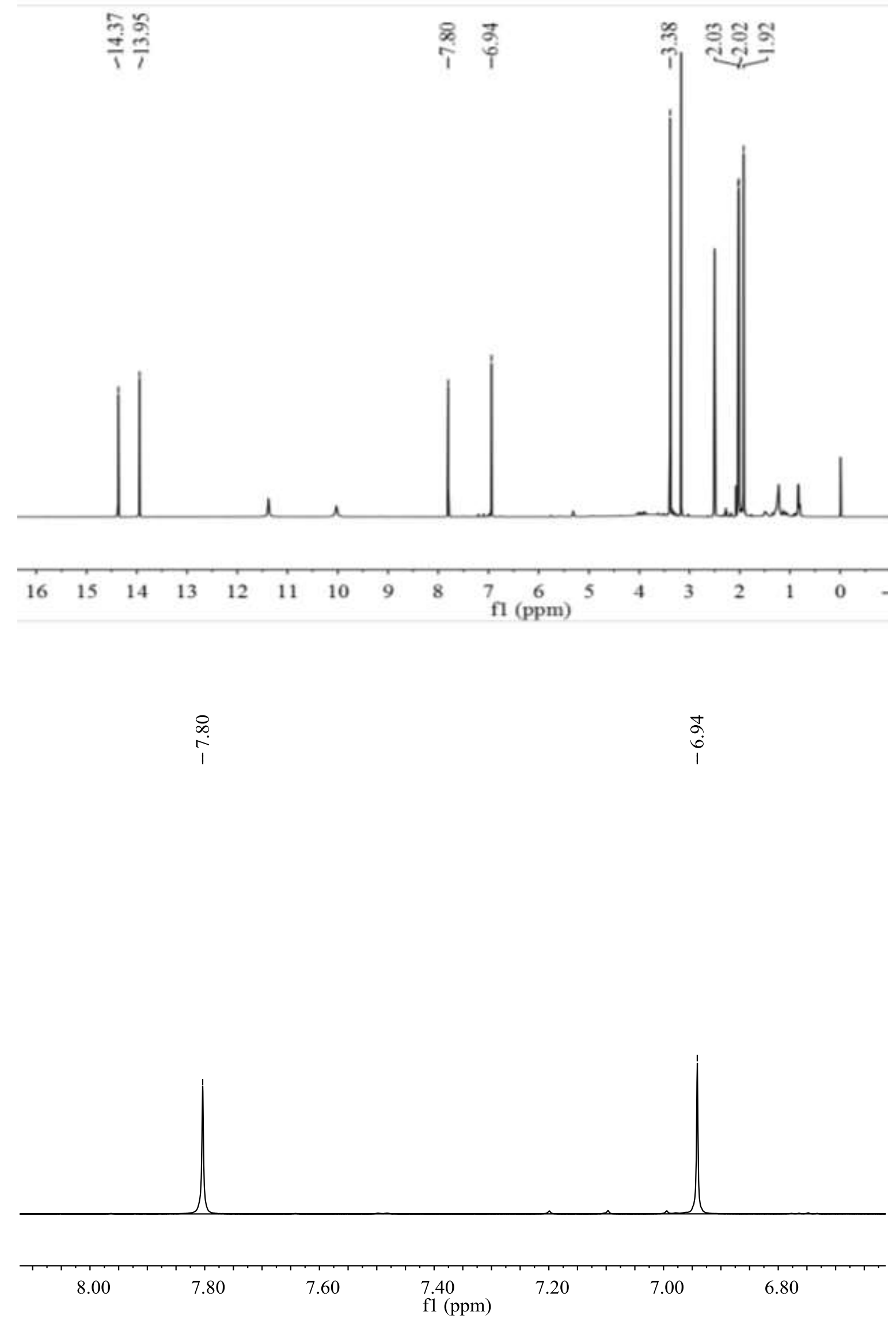

S42 ${ }^{1} \mathrm{H}$ NMR and the expansion spectra of the aromatic region for compound 9 (500 MHz, DMSO- $d_{6}$ ) 


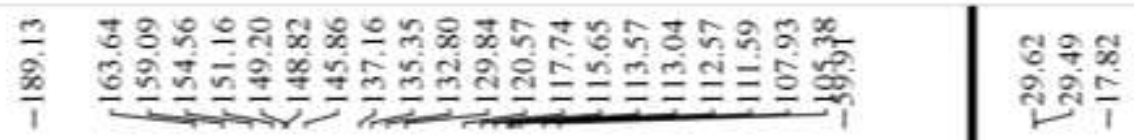

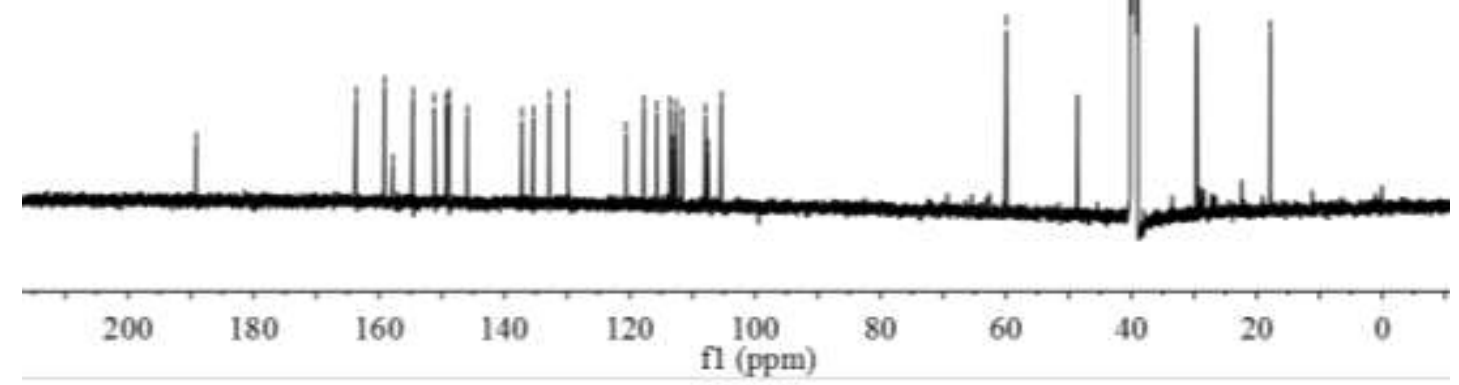

S43 ${ }^{13} \mathrm{C}$ NMR for compound 9 (125 MHz, DMSO- $\left.d_{6}\right)$

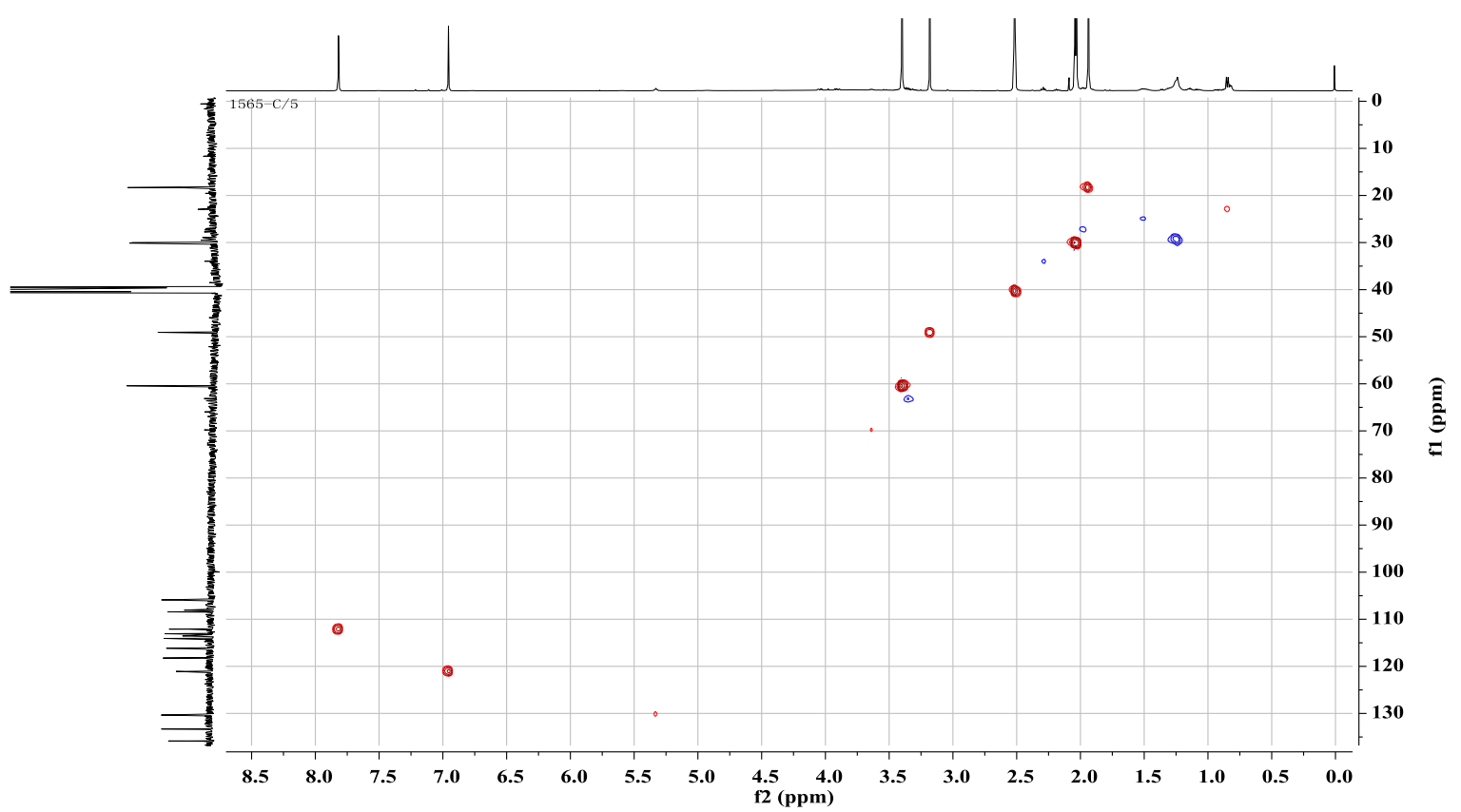

S44 HSQC for compound 9 (500 MHz, DMSO- $d_{6}$ ) 


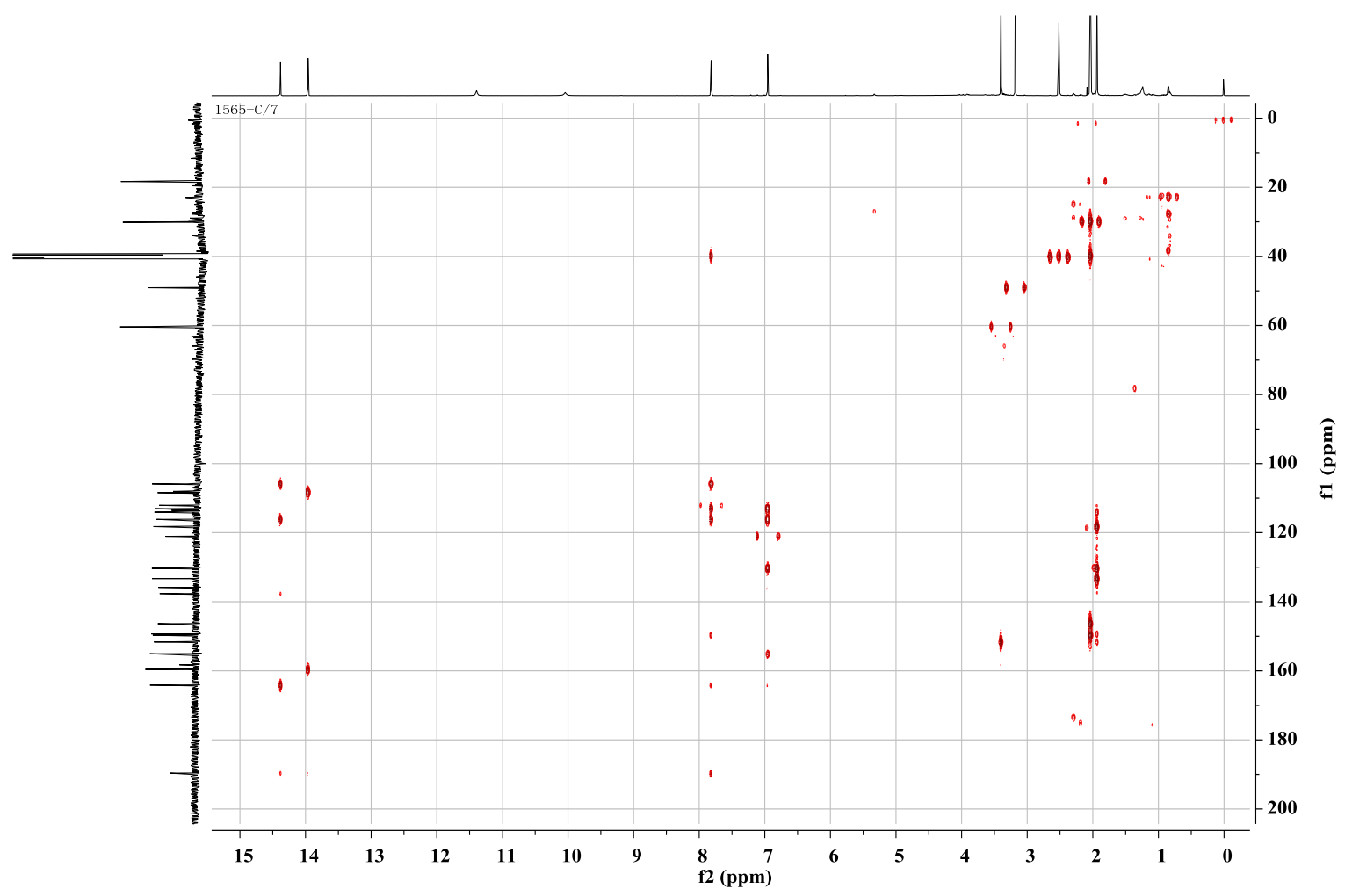

S45 HMBC for compound 9 (500 MHz, DMSO- $\left.d_{6}\right)$

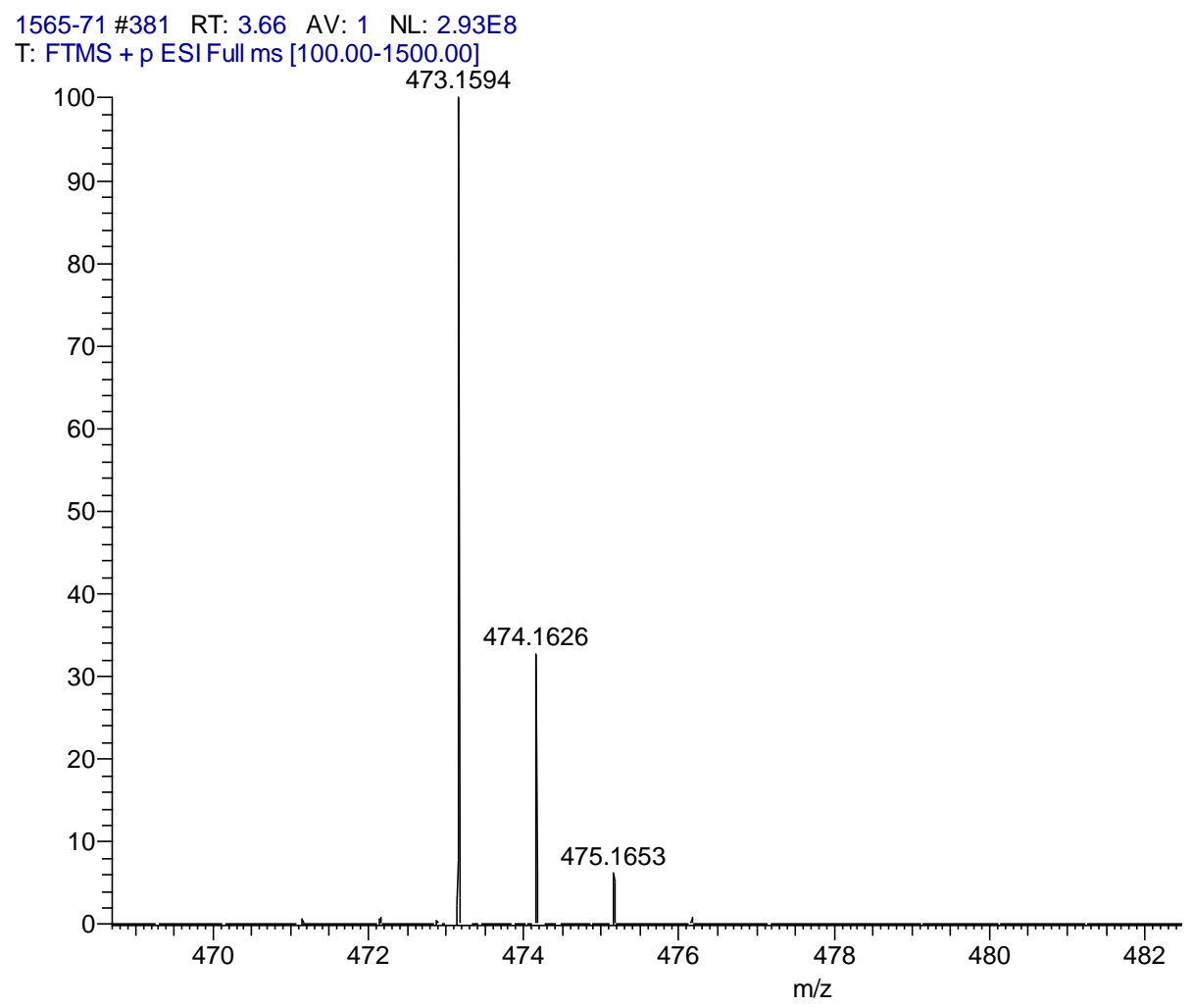

S46 HRESIMS for compound 10 

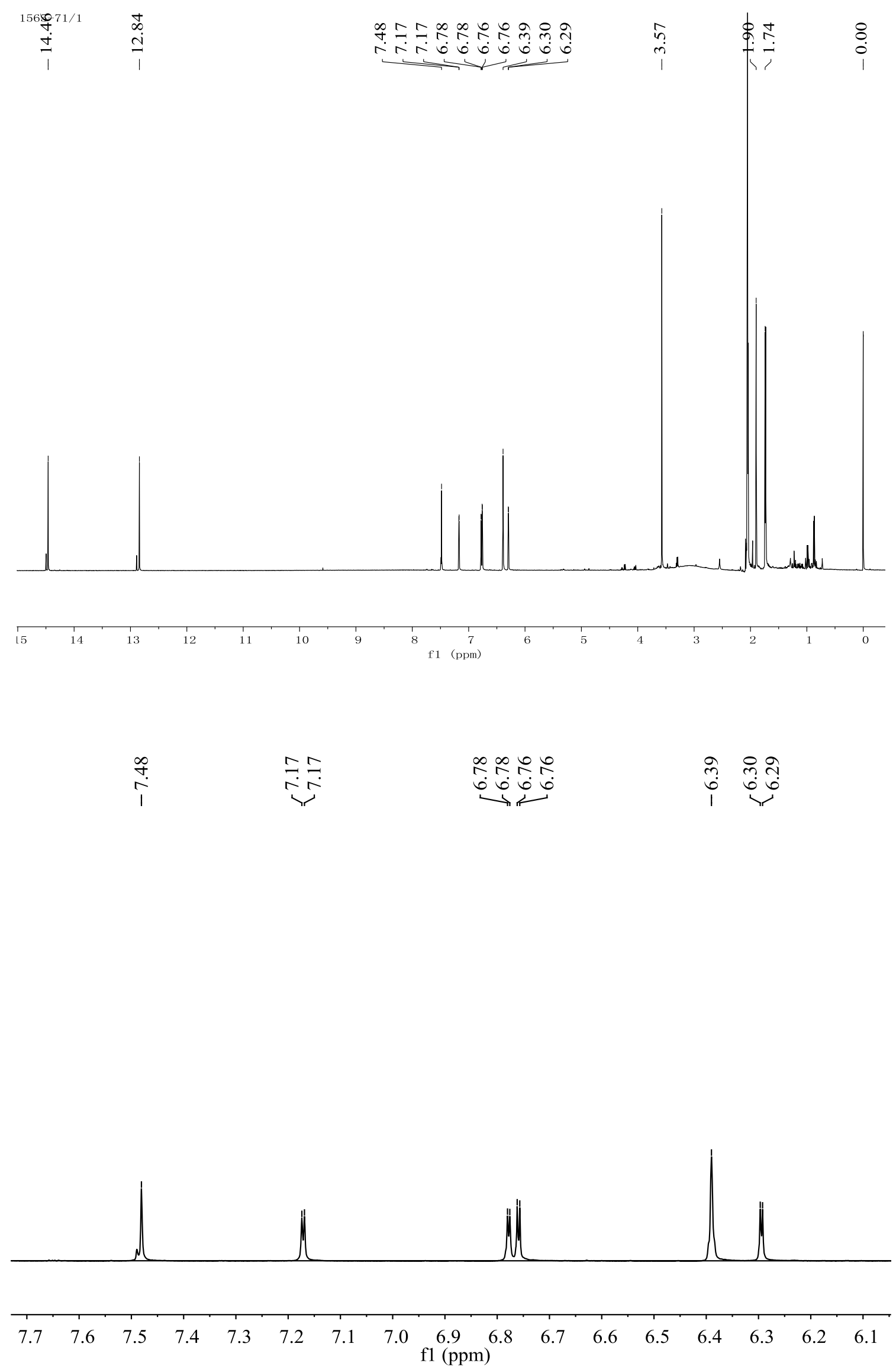

S47 ${ }^{1} \mathrm{H}$ NMR and the expansion spectra of the aromatic region for compound $10\left(500 \mathrm{MHz}\right.$, Acetone- $\left.d_{6}\right)$ 

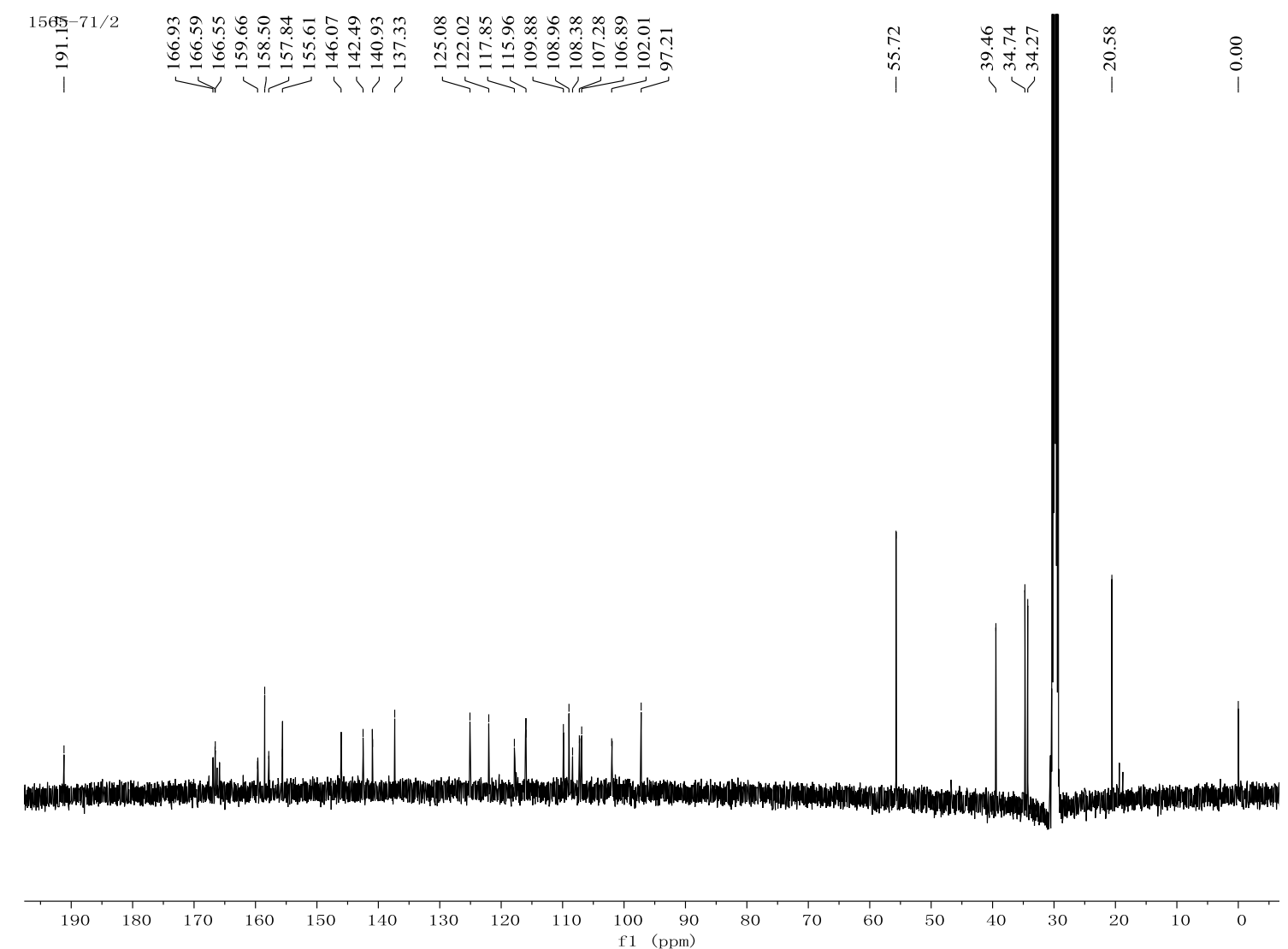

S48 ${ }^{13} \mathrm{C}$ NMR for compound 10 (125 MHz, Acetone- $\left.d_{6}\right)$

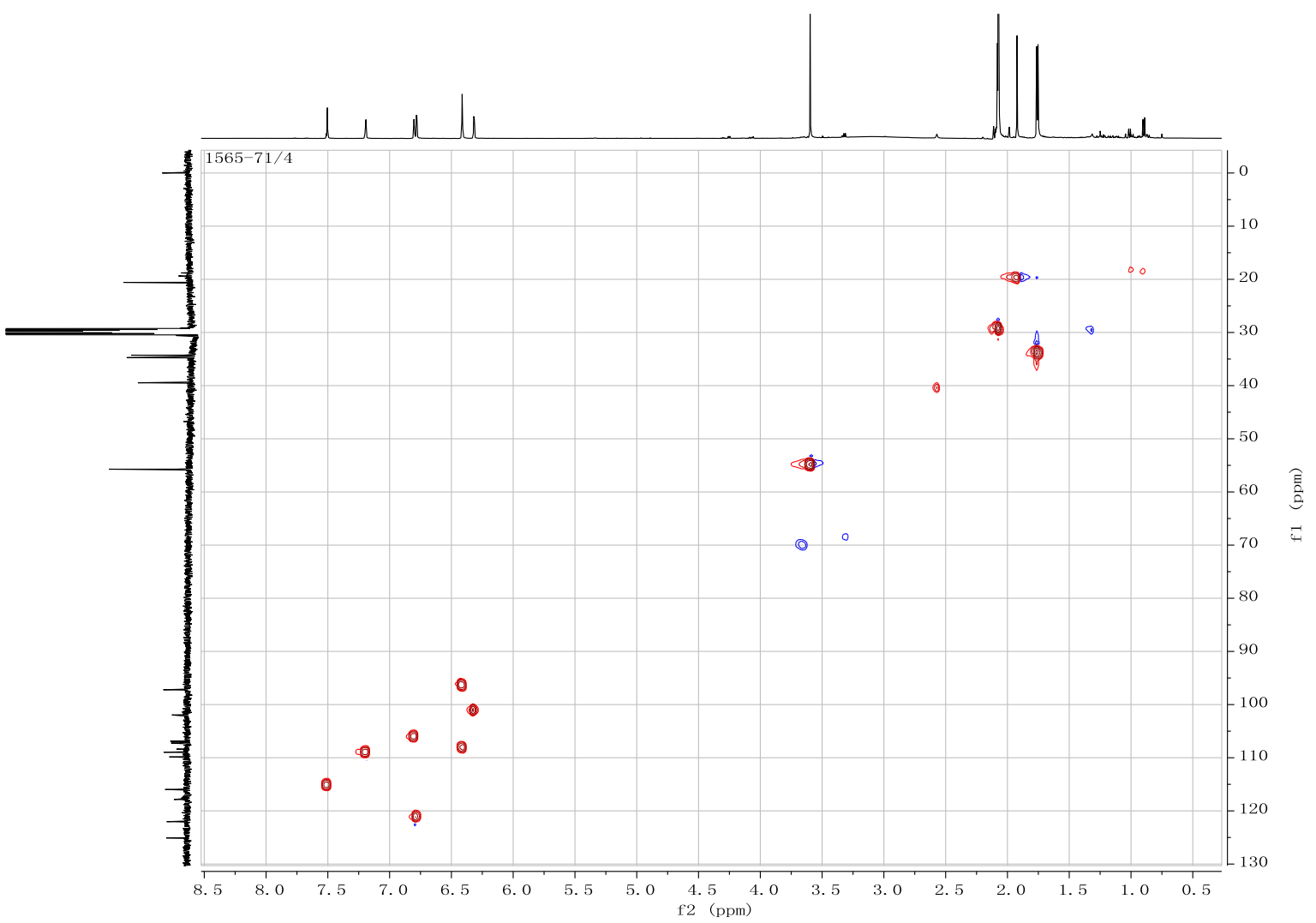

S49 HSQC for compound 10 (500 MHz, Acetone- $d_{6}$ ) 


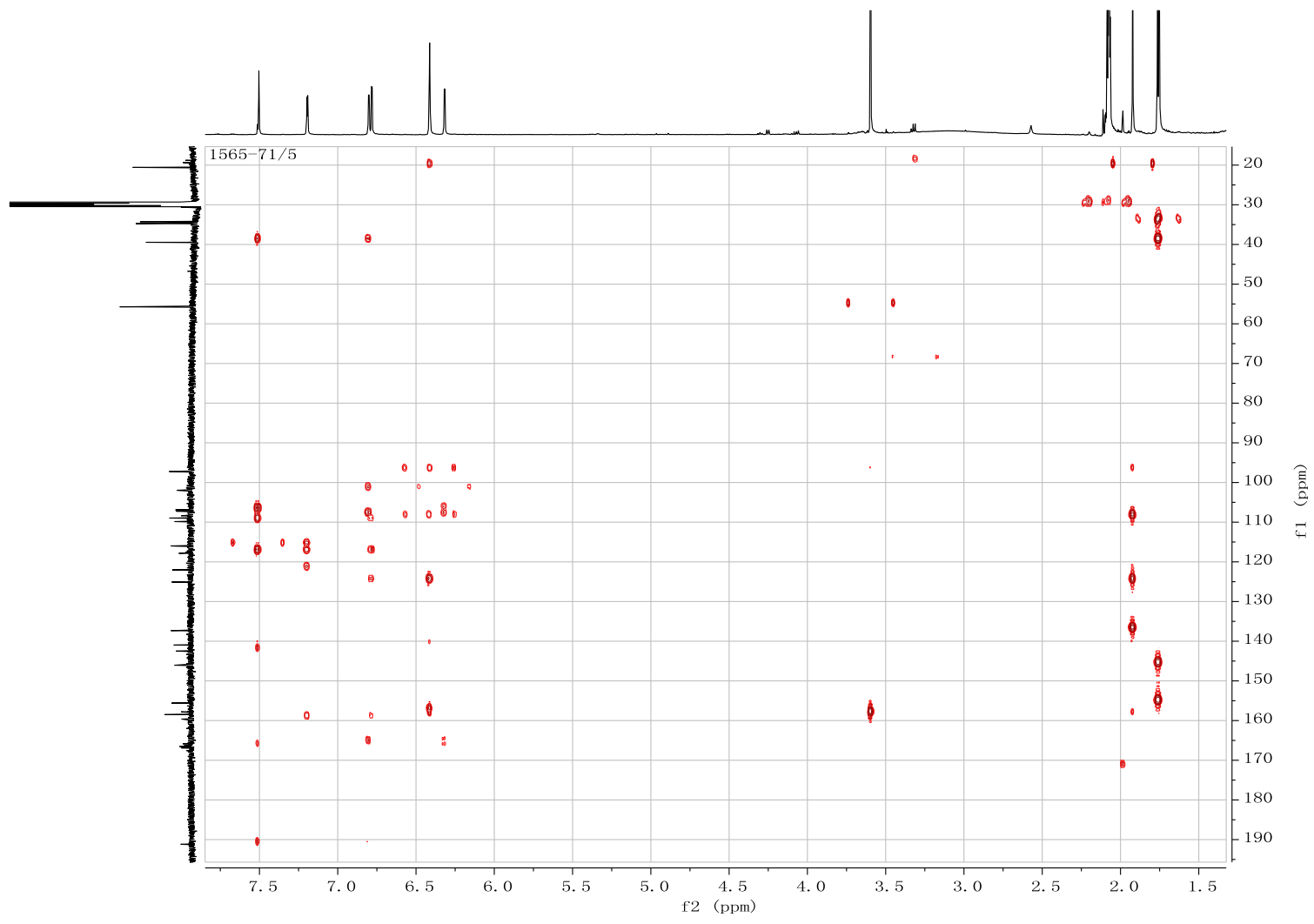

S50 HMBC for compound $10\left(500 \mathrm{MHz}\right.$, Acetone- $\left.d_{6}\right)$ 